\title{
Şanghay İş Birliği Örgütü: Çıkarlar/Öncelikler ve Bölgesel İş Birliği Arasında Bir Denge Arayışı
}

\section{Shanghai Cooperation Organization: A Balance Seeking Between Interests/Priorities and Regional Cooperation}

\author{
İbrahim ARSLAN*
}

$\ddot{O} z$

Bu çalışmanın amacl; kuruluşu 15 Haziran 2001 tarihinde Şanghay'da (Çin) ilan edilen Şanghay İs Birliği Örgütü' 'nün yapısını, ana faaliyet alanlarını, sorunların analiz etmek ve geleceğine yönelik öngörülerde bulunmaktır. Birleşmiş Milletler'de veto yetkisine sahip Çin Halk Cumhuriyeti ve Rusya Federasyonu, Asya merkezli hükümetlerarası bir kuruluş olan Şanghay Işs Birliği Örgütü'nün kuruluşundan bu yana üyesidir. Günümüzde ise uluslararası alanda etki yaratma kapasiteleri, çıkarlarl/öncelikleri birbirinden farklı olmasina rağmen, bölgesel iş birliğini benimseyen sekiz ülke örgütün üyesidir. Altı diyalog ortağl ve dört gözlemci statüsünde ülkesi olan örgüt, 2025 yllına kadar yürürlükte olan Şanghay İş Birliği Örgütü'nün Kalkinma Stratejisi doğrultusunda, bölgesinde barış ve istikrarı güçlendirmeyi; ticaret, ekonomik, kültürel ve insani yardımları teşvik etmeyi taahhüt etmektedir. Güvenlik.

Anahtar Kelimeler: Çin, Rusya, Şanghay İş Birliği Örgütü, ŞiÖ,

\footnotetext{
* Dr. Öğr. Üyesi, Üsküdar Üniversitesi, Siyaset Bilimi ve Uluslararası İlişkiler Bölümü, e-posta: ibrahim.arslan@uskudar.edu.tr.
} 


\section{Abstract}

The aim of this study is to analyze the structure, main areas of activity and problems, and foresee the future of the Shanghai Cooperation Organization (SCO), of which foundation was announced on June 15, 2001, in Shanghai (China). The People's Republic of China and the Russian Federation, which have veto powers in the United Nations, have been members since the establishment of the SCO, an Asian-based intergovernmental organization. Despite the fact that their capabilities to create influence in the international arena, and interests/priorities are different from each other, the SCO, now, has eight member countries adopting regional cooperation. Additionally, the organization has six dialogue partners, as well as four observer countries. The SCO is committed to strengthen peace and stability, and to promote trade, economic, cultural, and humanitarian ties in line with the Shanghai Cooperation Organization's Development Strategy to 2025.

Keywords: China, Russia, Shanghai Cooperation Organization, SCO, Security.

\section{Giriş}

Sovyetler Birliği’nin dağılması üzerine, Çin Halk Cumhuriyeti** ile Sovyetler Birliği arasındaki sınırın belirlenmesi konusunda, geçmişten gelen sorunların çözümlenmesi ve yeni siyasi duruma göre oluşan sınırların belirlenmesi amacıyla, bağımsızlığına yeni kavuşan ülkelerden Kazakistan, Kırgızistan ve Tacikistan, 1990'ların başında, Çin ile görüşmelere başladı. Devamında, bu sorunları sona erdirmek için, ilgili devletler arasında, çok taraflı bir çerçeve kapsamında, müzakereler ve güven artırıcı önlemler süreci başlatıldı. Orta Asya ülkeleri ve Çin, Rusya Federasyonu'nun ${ }^{* * *}$ bölgedeki rolünün ve etkisinin bilincinde olduklarından, Moskova da bu müzakerelere davet edildi.

Çin, Orta Asya cumhuriyetlerini sınır anlaşmazlıkları konusunda

\footnotetext{
** Bundan sonra Çin olarak ifade edilecektir.

*** Bundan sonra Rusya olarak ifade edilecektir.
} 
Şanghay İşbirliği Örgütü:

Çıkarlar/Öncelikler ve Bölgesel İş Birliği Arasında Bir Denge Arayışı

uzlaşmaya zorlama pozisyonundayken, bu yönde bir politika izlemedi. $\mathrm{Bu}$ yaklaşım, Çin'in, muhataplarının yeni ulus devletlerini oluşturma çabalarına hassasiyet gösterdiğinin bir göstergesi olarak algılandı. İlave olarak, görüşmelere Rusya'nın katılımının sağlanması, tüm tarafların bölgede uluslararası ilişkiler bağlamındaki gelişmelerde, Rusya'nın önemli bir aktör olduğunu ${ }^{1}$ kabul ettiklerinin; Çin'in, Rusya'nın aleyhine bölgede konumunu güçlendirmeye çalışmadığının, aksine Rusya ile birlikte hareket etmeyi tercih ettiğinin güçlü bir işaretiydi.

Çok taraflı sınır müzakerelerinde sağlanan ilerlemedeki başarı, 1996'dan itibaren görülmeye başlandı. Sınır bölgelerinde bulunan askerî kuvvetlerin karşılıklı olarak azaltılmasına ilişkin güven artırıcı önlemlere yönelik anlaşmalar; Çin, Kazakistan, Kırgızistan, Rusya ve Tacikistan devlet başkanları tarafindan 1996'da Şanghay'da ve 1997'de Moskova'da imzalandı. Bu anlaşmaların nihai belgelerinin 1998'de Alma-Ata'da, 1999'da Bişkek'te ve 2000'de Duşanbe'de gerçekleştirilen zirvelerde imzalanmas1; bölgedeki barış, güvenlik ve istikrarın artmasına ve bölgesel iş birliğinin gelişmesine önemli katkı sağladı. ${ }^{2}$ Dönemin Çin Devlet Başkanı Jiang Zemin, bu gelişmelerin yaşandığ 1 süreçte, Çin, Kazakistan, Kırgızistan, Rusya ve Tacikistan arasında güvenlik, ticaret ve diğer konularda iş birliğini derinleştirmeye yönelik olarak, bu ülkelerin devlet başkanlarına, yıllık zirve toplantısı düzenlenmesi çağrısında bulundu. Yaygın tanımlamayla "Şanghay Beşlisi" zirvesi olarak bilinen yıllık toplantıların ilki, beş ülkenin liderlerinin bölgesel ve uluslararası konularda görüş alışverişinde bulunmalarını sağlamak maksadiyla, Nisan 1996'da, Çin'in Şanghay kentinde gerçekleştirildi. Jiang Zemin, zirvede yaptığı konuşmada, Şanghay Beşlisi mekanizmasını mükemmelleştirmeye yönelik olarak aşağıdaki önerileri sundu: ${ }^{3}$

\footnotetext{
${ }^{1}$ Stephen Aris, "Shanghai Cooperation Organization Mapping Multilateralism in Transition”, International Peace Institute, No: 2, 2013, p.1-2.

2 "Declaration of Shanghai Cooperation Organization", People's Daily, June 15, 2001, http://en.people.cn/200106/15/eng20010615_72738.html, (Erişim Tarihi: 22.5.2018)

3 "Jiang: Perfecting 'Shanghai Five' Mechanism", People's Daily, July 5, 2000, http://en.people.cn/english/200007/05/eng20000705_44747.html (Erişim Tarihi: 15.4.2018)
}

\section{1}

Güvenlik Stratejileri

Cilt: 15

Say1: 30 
292

Güvenlik Stratejileri

Cilt: 15

Sayı: 30

- Beş ulus, ulusal ve bölgesel güvenlik ve istikrar konusunda iş birliğini derinleştirmeli;

- Ekonomik ve ticari konularda ikili ve çok taraflı iş birliği geliştirilmeli;

- Uluslararası alanda beş ülke arasındaki koordinasyon güçlendirilmeli;

- Şanghay Beşlisi çerçevesinde belirli projelere yönelik çeşitli düzeylerde ve farklı alanlarda danışma mekanizması geliştirilmelidir.

Şanghay Beşlisi'ne ilave olarak Özbekistan'ın katılımıyla, 2001'de, Şanghay İş Birliği Örgütü-ŞİÖ (Shangai Cooperation Organization) kuruluş deklarasyonu imzaland $1{ }^{4}$ ŞiÖ'nün amaçları:

- Üye ülkeler arasında karşılıklı güven ve iyi komşuluğu güçlendirmek;

- Politik, ekonomik ve ticari, bilimsel ve teknolojik, kültürel, eğitim, enerji, iletişim, çevre ve diğer alanlarda komşu ülkeler arasında etkili iş birliğini teşvik etmek;

- Bölgesel barışı, güvenliği ve istikrarı ortaklaşa korumak;

- Demokratik, adil, rasyonel bir uluslararası politik ve ekonomik düzen tesis etmek, olarak belirlendi. ${ }^{5}$

Şiö Şartı, 2002'de St. Petersburg'da düzenlenen Devlet başkanları toplantısında imzalandı ve 19 Eylül 2003'de yürürlüğe girdi. ${ }^{6}$ Devlet ve Hükümet Başkanları Konseyi'nin, 8-9 Haziran 2017 tarihlerinde, Astana'da gerçekleştirdikleri tarihî toplantıda, Hindistan ve Pakistan'a

4 "Declaration on the establishment of the Shanghai Cooperation Organization", p.1, http://www.gsdrc.org/docs/open/regional-organisations/sco,\%202001,\%20establishing \%20declaration.pdf (Erişim Tarihi: 15.4.2018)

5 "Declaration on the establishment of the Shanghai Cooperation Organization", p. 1, Article 2, http://www.gsdrc.org/docs/open/regional-organisations/sco,\%202001,\%20 establishing\%20 declaration.pdf (Erişim Tarihi: 15.4.2018)

6 "History of the SCO", http://eng.sectsco.org/docs/about/faq.html\#2, (Erişim Tarihi: 22.5.2018) 
Şanghay İşbirliği Örgütü:

Çıkarlar/Öncelikler ve Bölgesel İş Birliği Arasında Bir Denge Arayışı

tam üyelik statüsü verildi. Hindistan ve Pakistan'la birlikte Şiö, yaklaşık olarak dünyadaki kara parçalarının \%23'ünü, dünya nüfusunun \%45'ini ve küresel Gayrısafi Hâsılanın \%25'ini kapsayan bir uluslararası kuruluş haline geldi. ${ }^{7}$ Şi̇Ö'nün gözlemci ülkeleri Afganistan, Beyaz Rusya, İran ve Moğolistan'dır. Diyalog ortağı olan ülkeler ise Azerbaycan, Ermenistan, Kamboçya, Nepal, Sri Lanka ve Türkiye'dir.

$\mathrm{Bu}$ noktada, uluslararası bir örgüt olan Şiö bağlamında, uluslararas1 örgüt kavramının tanımlanmasının gerekli olduğu düşünülmektedir. Uluslararası Hukuk Komisyonu (UHK), uluslararas1 örgütlerle ilgili ilk tanımını 1956'da yapmış; 2003'de ise buna uygun biçimde, uluslararası örgüt tanımını güncellemiştir. Buna göre uluslararası örgüt, "Anlaşmayla veya uluslararası hukukun düzenlediği başka bir belgeyle kurulan ve kendi hukuki şahsiyetine sahip olan kuruluşlardır."8 Çağıran, UHK'nın bu tanımını esas alarak, uluslararası örgütü "Belirli işlevleri yerine getirmek amacıyla anlaşmayla kurulan, kurumsal yapısı ve kendine ait organları bulunan, uluslararası şahsiyeti olan ve süreklilik arz eden devletler birliğidir" ${ }^{9}$ biçiminde tanımlamaktadır.

Son dönemde "uluslararası" nitelemesi yerine "hükümetlerarası" nitelemesinin yaygın olarak kullanıldığı görülmektedir. Hükümetlerarası nitelemesinin, uluslararası örgütlerin, sadece devletler tarafindan kurulduğu ve devletlerarası iş birliğine hizmet ettiği görüşüne ilişkin olarak tercih edildiği belirtilebilir. Bununla birlikte, uluslararası örgüt kurucularının tamamının devlet olması gerekmemektedir. Örgüt kelimesi ise, her türlü uluslararası kuruluşu (birlik, komisyon, büro, fon, Pazar) ifade etmektedir. ${ }^{10}$ Devletler, tek başlarına yapamadıkları veya birlikte yapmanın daha uygun olduğunu düşündükleri işleri gerçekleştirmek üzere uluslararası örgüt kurmaktadırlar. Bu bağlamda,

\footnotetext{
${ }^{7}$ Alexander Gabuev, "Bigger, Not Better: Russia makes the SCO a Useless Club", Carnegie Moscow Center, 23.06.2017, https://carnegie.ru/commentary/71350 (Erişim Tarihi: 20.5.2018)

${ }^{8}$ Yearbook of the International Law Comission, Vol.I , 2003, p. 87.

${ }^{9}$ Mehmet Emin Çağıran, Uluslararası Örgütler, Turhan Kitabevi, Ankara 2013, s. 6.

${ }^{10}$ A.g.e., s. 7.
}

\section{3}

Güvenlik Stratejileri

Cilt: 15

Say1: 30 
294

Güvenlik Stratejileri

Cilt: 15

Sayı: 30 uluslararası örgütler, devletlerarası iş birliğinin kurumsallaşmış hali ${ }^{11}$ olarak da tanımlanabilir. Hükümetlerarası örgütler, tek bir amaca yönelik kurulabileceği gibi, birden çok amacı da kapsayabilmekte, küreselbölgesel, yeni üyeliklere açık-yeni üyeliklere kapalı da olabilmektedir. ${ }^{12}$

Uluslararas1 örgütler, bölgeselleşmenin gerçekleşmesini ve güçlenmesini sağlamaktadır. Bölgeselleşme, dünyadaki belirli bölgeleri kapsayan devletlerarasında yeni etkileşim biçimlerini oluşturan, istikrarı esas alan, küresel düzenin gelişimine yönelik bir eğilim olarak ortaya çıkmıştır. Günümüzde her geçen gün, daha fazla ülke, komşularıyla karşılıklı bağımlılığ artıran istikrarlı bir sistem kurmaya çalışmakta, böylece bu ülkeler mevcut potansiyellerini birleştirerek bölgesel sorunlarını çözmek için ortak çaba sarf etmektedir. ${ }^{13} \mathrm{Bu}$ tür ortaklıkların kurulması ve geliştirilmesinde; bölgesel sorunların ele alınmasına duyulan ihtiyaç, katılımcıların diyalog için istekli olmaları, ilgili tüm taraflar için yararlı ve sürdürülebilir kalkınmaya ulaşmaya yönelik ortak yaklaşım arayış1, ${ }^{14}$ öne çıkan temel etkenlerdir. Sovyetler Birliği'nin dağılmasından sonra, bölgedeki devletlerin aralarındaki sorunlar ve Rusya'nın bu coğrafyadaki etkisi göz ardı edilerek; Orta Asya'nın, coğrafi ve tarihî nedenlerden dolayı alt bölge ${ }^{15}$ olarak tanımlandığı görüldü. Bölge ülkeleri, bu süreçte, farklı uluslararası örgütler oluşturarak Soğuk Savaş sonrası gelişen yeni uluslararası ortama uyum sağlamaya çalıştı. ŞīÖ'nün kuruluşu bu bağlamda değerlendirilebilir.

Diyalog ortağı ve gözlemci ülkelerle birlikte geniş bir coğrafyada faaliyetlerini sürdürmesine rağmen, gelinen noktada, ŞïÖ'nün çok güçlü bir yapısı olduğu ileri sürülememektedir. Bu durum, çalışmanın

${ }^{11}$ A.g.e., ss. 9-10.

12 Faruk Sönmezoğlu (der.), Uluslararası İlişkiler Sözlüğü, 4. Basım, DER Yayınlar1:184, İstanbul 2010, s. 673.

${ }^{13}$ Rashid Alimov, "The Shanghai Cooperation Organisation: Its role and place in the development of Eurasia", Journal of Eurasian Studies, Asia-Pacific Research Center, Hanyang University, 2018, p.114.

${ }^{14}$ A.g.e.

${ }^{15}$ Roy Allison, "Regionalism, regional structures and security management in Central Asia", International Affairs, 80.3, 2004, p. 466. 
Şanghay İşbirliği Örgütü:

Çıkarlar/Öncelikler ve Bölgesel İş Birliği Arasında Bir Denge Arayışı

sorunsalının tespiti bağlamında, ŞiÖ’nün küresel ölçekte bir ittifaka dönüşmesini engelleyen/geciktiren faktörlerin neler olduğunun bilinmesi ihtiyacını ortaya çıkarmaktadır. Çalışma, "uluslararası bir örgütte başat güçlerin çıkarlarının uyumlaştırılamaması halinde, bu örgütün etkinliğini artırabilmesinin daha uzun süre gerektireceği" iddiasına dayandırılmaktadır. BM'de veto yetkisine sahip iki ülkenin Şiö'ye üye olması ve bu ülkelerden Çin'in, uluslararası alanda yükselen güç konumunu sürdürmesi nedeniyle, dünya düzeninin yeniden şekillenmekte olduğunun tartışıldığı bir dönemde, ŞİÖ'nün etki kapasitesinin ortaya konulmasına yönelik bu çalışmanın, ittifak ilişkileri bağlamında, uluslararası ilişkiler disiplinine katk1 sağlayacağı düşünülmektedir. Çalışma; Şanghay İş Birliği Örgütü'nün Yapısı ve Esas İş Birliği Alanları, Şanghay İş Birliği Örgütü'nün Karşılaştı̆̆ı Sorunlar ve Şanghay İş Birliği Örgütü'nün Geleceği başlıkları altında gerçekleştirilecek, ŞiÖ belgelerinin yanı sıra, literatür taramasından edinilen bilgi ve bulgulardan yararlanarak Sonuç başlığı altında örgütün geleceğine ilişkin önerilerde bulunulacaktır.

\section{1. Şanghay İş Birliği Örgütü’nün Yapısı ve Esas İş Birliği Alanları}

ŞīÖ'nün iç politikası, karşılıklı güven, karşılıklı yarar, eşitlik, karşı1ıklı danışma, kültürel çoğulculuğa saygı, birlikte kalkınma prensiplerine dayanmaktadır. Örgütün dış politikası ise bağlantısızlık, açıklık ve üçüncü bir ülkeyi hedef almama üzerine inşa edilmektedir. ${ }^{16}$ Soğuk Savaş döneminin sonlarına doğru öne çıkan Neoliberal Kurumsalc1l1k (Neoliberal Institutionalism) teorisi, ŞïÖ'nün oluşum gerekçesini açıklamaktadır. Neoliberal Kurumsalcılık, devletlerin çıkarlarını gözeteceğini, bununla birlikte, refah devleti (welfare state) anlayışını benimseyen rasyonel yapılar olarak iş birliğine de gideceklerini öngörmektedir. $\mathrm{Bu}$ bağlamda, Neoliberal Kurumsalcılık teorisi; rasyonaliteye realistlerden farklı anlam yükleyerek, devletler arasındaki

16 "The Shanghai Cooperation Organisation", http://eng.sectsco.org/about_sco/ (Erişim Tarihi: 15.4.2018) 
iş birliğinin nedeninin, devletlerin rasyonal davranmalarında aranması gerektiğinin altını çizmektedir. ${ }^{17}$ Kendi çıkarlarını gerçekleştirmeyi amaçlayan yapılar olarak devletler, bu amaçlarına ulaşmak için, uluslararası kuruluşları, Neoliberal Kurumsalcıllğın merkezinde görmektedir. ${ }^{18} \mathrm{Bu}$ bağlamda; yüzölçümü, nüfusu, gayrisafi millî hâsılası ve uluslararası politikada etki derecesi bakımından aralarında çok az benzerlik olan Çin, Rusya ve Orta Asya ülkelerinden Kazakistan, Kırgızistan, Özbekistan ve Tacikistan geleneksel olmayan güvenlik anlayışı çerçevesinde, uluslararası terörizm, etnik ve dinî ayrımc1lığa karş1, 2001'de ŞīÖ'nün kuruluşunu ilan etti. ${ }^{19}$

\section{1. ŞİÖ’nün Yaptsı}

Örgüt; Devlet Başkanları Konseyi (Heads of State Council), Hükümet Başkanları Konseyi (Heads of Government Council), Dışişleri Bakanları Konseyi (Council of Ministers of Foreign Affairs), Bakanlar ve/veya Kurum Liderlerinin Toplantıları (Meetings of Heads of Ministries and/or Agencies), Ulusal Koordinatörler Konseyi (Council of National Coordinators), Teröre Karşı Bölgesel Yap1 (Regional Anti-Terrorist Structure-RATS), ŞIÖ Sekreteryası'ndan (SCO Secretariat) oluşmaktadır. Örgütte ayrıca, iki hükümetdışı kuruluş bulunmaktadır. Bunlar, ŞiöO İş Konseyi (Business Council of the Shanghai Cooperation Organisation) ve ŞiÖ Bankalararası Konsorsiyum'dur (SCO Interbank Consortium) ${ }^{20}$

Devlet Başkanları Konseyi: ŞiÖ’nün en üst organıdır. Esas karar organı olan Konsey, üye devletlerin devlet başkanlarından oluşmaktadır.

${ }^{17}$ Yücel Bozdağlığlu, "Liberalizm", Haydar Çakmak (ed.), Uluslararası İlişkiler "Giriş, Kavram ve Teoriler", Platin, Ankara 2007, 154-161, ss. 160-161.

${ }^{18}$ Arthur A. Stein, "Neoliberal Institutionalism", Christian Reus-Smit and Duncal Snidal, in The Oxford Handbook on International Relations, Oxford University Press, New York, 2008, 201-221. p. 208.

19 Weiqing Song, "Interests, Power and China's Difficult Game in the Shanghai Cooperation Organization (SCO)", Journal of Contemporary China, Taylor \& Francis, Vol: 23, No: $85,2014,85-101$, p. 85.

20 "Structure of the Shanghai Cooperation Organisation", http://eng.sectsco.org/ structure/, (Erişim Tarihi: 20.5.2018) 
Şanghay İşbirliği Örgütü:

Çıkarlar/Öncelikler ve Bölgesel İş Birliği Arasında Bir Denge Arayışı

Normal koşullar altında Konsey, sadece ŞiOÖ'nün yıllık zirvesinde 297 toplanır ve örgütün önümüzdeki yıla yönelik olarak politik, gündemini belirler. Konseye, toplantının icra edildiği ülkenin devlet başkanı başkanlık yapar. Toplantı yeri, ülke isimlerinin Rus alfabesindeki sirasina göre belirlenir.

Hükümet Başkanları Konseyi: Yılda bir kez toplanır ve örgütün bütçesini onaylar.

Dışişleri Bakanları Konseyi: Örgütün belirli sorunlarını tartışır ve Devlet Başkanları Konseyi'nin toplantılarının hazırlığını yürütür. Bu Konsey, genellikle, Devlet Başkanları Konseyi'nden bir ay önce toplanır. İki üye ülkenin talebi ve diğer dışişleri bakanlarının rızasıyla olağanüstü toplantı düzenlenebilir.

Ulusal Koordinatörler Konseyi: Üyeler, ülkelerin kendi ulusal karar ve süreçlerine göre seçilir. Bu Konsey; Devlet Başkanları Konseyi, Hükümet Başkanları Konseyi ve Dışişleri Bakanları Konseyi'nin toplantılarının hazırlığını yürütür. Yılda en az üç kez toplanır.

Sekreterya: Pekin'de bulunan Sekreterya, Şiö çerçevesinde desteklenen faaliyetlere organizasyon, teknik ve bilgi desteğinin sağlanmasından sorumlu daimi icra organıdır. ${ }^{21}$ Dışişleri Bakanları Konseyi'nin önerdiği, Devlet Başkanları Konseyi'nin atadığı bir Genel Sekreter tarafindan yönetilir. Genel Sekreter'in görev süresi, uzatma olmaksızın üç yıldır. ${ }^{22}$ Sekreterya, üye ülkelerden, tarafsız olarak çalışmak üzere, sürekli görevlendirilen personelden oluşmaktadır. Her üye ülkenin görevlendireceği personelin sayısı, ŞïÖ bütçesine yaptıkları katkı oranında belirlenmektedir. Sekreterya, gözlemci ve diyalog ortağı ülkelerin yanı sıra, hükümet dışı kuruluşlarla da görüşerek, örgütün faaliyetlerini koordine eder.

Şi̇Ö’nün bölgenin “üç şeytani gücü” olarak tanımladığı terörizm, aşırıcılık ve bölücülük gibi konular esas alınarak, 15 Haziran 2001'de

\footnotetext{
21 "General information about the SCO Secretariat", http://eng.sectsco.org/secretariat/, (Erişim Tarihi: 22.5.2018)

${ }^{22}$ A.g.e.
}

Güvenlik Stratejileri

Cilt: 15

Say1: 30 

konuşlandırılmıştır. RATS, ŞiÖ Şartı ve Terörizm, Ayrımcılılık ve Așırılığa Karşı Şanghay Konvansiyonu (The Shanghai Convention on Combating Terrorism, Separatism and Extremism) ${ }^{23}$ esaslarına uygun olarak faaliyetlerini sürdürmektedir. RATS, iki organdan oluşmaktadır. İlki, ilgili üye ülkelerdeki terörle mücadele çabalarından sorumlu bakanlardan oluşan, faaliyetlerin genel gidişatını ve gündemini belirlemek için düzenli olarak toplanan bir konseydir. İkincisi ise, Konsey tarafindan belirlenmiş gündemin uygulanmasından sorumlu, daimi bir yürütme komitesidir. ${ }^{24}$ Komite, Özbekistan'ın başkenti Taşkent'te bulunmaktadır. ${ }^{25}$

ŞİÖ Bankalararası Konsorsiyum: Devlet Başkanları Konseyi'nin 26 Ekim 2005'te aldığ1 bir kararla kurulmuştur; ${ }^{26}$ ortak yatırım projelerini değerlendirmekte ve bu projeler için kredi sağlamaktadır.

ŞIÖ İ̧ Konseyi: 14 Haziran 2006'da Şanghay'da kurulmuştur. ŞiÖ İş Konseyi Sekreteryası Moskova merkezli olarak oluşturulmuştur. ${ }^{27}$ İş Konseyi, üye ülkelerin iş toplulukları ve finansal kuruluşları arasındaki etkileşimi ve iş birliğini kolaylaştırarak ŞiÖ projelerinin uygulanmasını desteklemek için tasarlanmış bir hükümet dışı kuruluştur. Ayrıca, projelerin etkinliğini artırmak ve yatırımcılara projeler için kaynak bulma konusunda, bağımsız bir tavsiye organı olarak da hizmet vermektedir.

\subsection{Esas İş Birliği Alanları}

ŞiÖ, üye ülkeler arasında güvenlik, ekonomi ve kültür alanlarında iş birliği tesis etmektedir. Örgütün bütçesi, Sekreterya'nın ve organların

23 "The Shanghai Convention on combating terrorism, separatism and extremism", https://eurasiangroup.org/files/uploads/files/International_legal_documents/Conventio ns/ The_20Shanghai_20Convention.pdf (Erişim Tarihi: 22.5.2018)

${ }^{24}$ Stephen Aris, Shanghai Cooperation, a.g.e., p. 4.

25 "Regional Anti-Terrorist Structure", http://eng.sectsco.org/structure/\#6, (Erişim Tarihi: 22.5.2018)

${ }^{26}$ The Shanghai Convention on combating..., a.g.e.

${ }^{27}$ A.g.e. 
Şanghay İşbirliği Örgütü:

Çıkarlar/Öncelikler ve Bölgesel İş Birliği Arasında Bir Denge Arayışı

giderleri ile sınırlıdır. Proje finansmanlarının önemli bir bölümü, belirli projeleri desteklemek üzere, üye ülkelerden ve İş Konseyi veya Bankalararası Konsorsiyum içinde oluşturulan birliklerden sağlanmaktadır. Ortak güvenlik kaygılarıyla oluşturulan iş birliği, ŞīÖ'nün esasını oluşturmaktadır.

\section{9}

Güvenlik Stratejileri

Cilt: 15

Say1: 30

\subsubsection{Güvenlik}

1990'ların başında, sınır belirlenmesi çalışmaları esnasında oluşan gerginliği gidermeye yönelik görüşmelerden başlayarak, ŞïÖ'nün güvenlik gündemi, bölge ülkelerini, yalnızca bir üyenin çabasıyla etkili bir şekilde çözülemeyecek ulusötesi sorunların hâline odaklanmayı zorunlu kıldı. ŞïÖ, 1996'dan itibaren güven artırıcı önlemler, sınır bölgelerini istikrarsızlaştıran unsurlara karşı mücadele ve çatışmaların yayılmasının önlenmesinde başarılı oldu. Güven artırıcı önlemler bağlamında, 3000 kilometreden fazla olan tarihî Sovyet-Çin sınırında süregelen tartışmaların altı yıl içinde çözüme kavuşturulması, ${ }^{28}$ bölgede istikrarın artmasına önemli katkı sağladı.

Bölgede aktif olan ve "üç şeytani güç" olarak adlandırılan tehdide karşı verilen mücadele, kuruluşundan bu yana, ŞïÖ bünyesindeki iş birliğginin ana dayanağını oluşturmaktadır. Üye ülkelerin terörizme karşı etkili iş birliği, ABD'deki 11 Eylül terör saldırılarından önce, 15 Haziran 2001'de, "Terörizm, Ayrımcılık ve Aşırıcılıkla Mücadele" Şanghay Sözleşmesi'nin imzalanmasıyla başlatıldı. ${ }^{29} \mathrm{Bu}$ gündem, 1990'lı yıllarda, Orta Asya'daki istikrarsızlık ortamında geliştirilmiştir. Tacikistan'daki İç Savaş (1992-1997), ${ }^{30}$ rejim karşıtı grupların silahlı saldırıları (1999 ve 2000'de Tacikistan, Özbekistan ve Kırgizistan'da

\footnotetext{
${ }^{28}$ Pan Guang, "The SCO's Success in Security Architecture”, Ron Huisken (ed.) The Architecture of Security in the Asia-Pacific, ANU Press, 2009, 33-44, pp. 33-34.

29 "The Shanghai Convention on combating terrorism, separatism and extremism", https://eurasiangroup.org/files/uploads/files/International_legal_documents/Conventions/ The_20Shanghai_20Convention.pdf (Erişim Tarihi: 22.5.2018)

30 "Tajikistan Civil War", https://www.globalsecurity.org/military/world/war/ tajikistan.htm, (Erişim Tarihi: 14.5.2018)
} 

iç güvenlikle ilgili devam eden kaygılar, bölgedeki istikrarsızlığa verilebilecek örneklerdir. ${ }^{31}$

ŞiÖ, bölgedeki terörist, bölücü ve aşırı uç aktörlerin veritabanının derlenmesi, sürekli güncellenmesi ve istihbarat paylaşımı için, bir merkez olarak hizmet eden RATS'1 tesis etmiştir. ${ }^{32}$ RATS, üye ülkelerin liderleri tarafından, ulusötesi terörizmle mücadelede önemli bir yap1 olarak görülmektedir. 2004'te operasyonel hale gelen RATS'in faaliyetleri, bölgedeki terörist hareketlerin analizini, terör tehditi ile ilgili bilgi değişimini, karşı terör faaliyetleri ile ilgili tavsiyeleri, ŞİÖ'nün ortak güvenlik tatbikatlarının koordinasyonunu ve terörist unsurların finans kaynaklarının ortadan kaldırılmasını kapsamaktadır. ${ }^{33}$ RATS, insan hakları savunucuları tarafindan iki konuda eleştirilmektedir. Bunların ilki terörizm, ayrılıkçılık ve aşırılık tanımlarının belirsizliği ve bu kategorilerin görevdeki rejimlere karş1 çıkan tüm aktörleri kapsayacak şekilde genişletilebileceği yönündedir. İkincisi ise, veri tabanlarının geliştirilmesindeki faaliyetlerin gizliliği ve özellikle diğer üye ülkeler tarafından terörist, ayrılıkçı veya aşırı uç şüphelileri olarak belirlenen kişilerin zorla geri iadesi konusundaki endişeleri, kapsamaktadır. ${ }^{34}$ Üç kötülüğe karşı verilen mücadele, Şi̇Ö güvenlik gündeminin merkezindeki özelliğini korurken, diğer sorunların güvenlik alanına dâhil edilmesi, 2000'li yılların ortalarından bu yana sürmektedir. Şiö, bölgeye istikrarı sağlamak için, bütüncül bir yaklaşımın gerekli olduğunu ve güvenlik için uzun vadeli etkilere sahip olabilecek konuların da ele alınması gerektiğini savunmaktadır. ${ }^{35} \mathrm{Bu}$ bağlamda, ŞiÖ; organize suç, yasadışı uyuşturucu ticareti ve doğal afetlere kolektif

${ }^{31}$ Stephen Aris, Shanghai Cooperation, a.g.e., p. 5.

${ }^{32}$ A.g.e.

${ }^{33}$ Marcel de Haas, "War Games of the Shanghai Cooperation Organization and the Collective Security Treaty Organization: Drills on the Move!" The Journal of Slavic Military Studies, 29:3, 2016, 378-406, p. 381.

${ }^{34}$ Stephen Aris, Shanghai Cooperation, a.g.e., p. 5.

${ }^{35}$ A.g.e. 
Şanghay İşbirliği Örgütü:

Çıkarlar/Öncelikler ve Bölgesel İş Birliği Arasında Bir Denge Arayışı

tepkiler için, yanıt verme konularında da programlar geliştirmektedir.

Bölgede yasadışı uyuşturucu ticareti, 2000'li yılların ortalarından itibaren üzerinde etkinlikle durulması gereken bir sorun haline gelmiştir. Afganistan'da güvensizliğin artması, Afganistan'ın üretim alanlarından Orta Asya, Rusya ve Avrupa'ya yapilan kaçak uyuşturucu ticareti artış gösterdiğinden, bu konunun üzerinde durulması daha da önem kazandı. ŞiÖ, 2011-2016 yıllarında anti-narkotik bir strateji benimseyerek, bölge genelinde ortak bir tutum oluşturmak üzere, üyelerinin iç politikalarının koordinasyonuna yöneldi. ${ }^{36}$ ŞiÖ, yasadışı uyuşturucuyla mücadeleye odaklanan diğer bölgesel ve küresel yapılarla birlikte çalışmaktadır. RATS, 2010 yılında Birleşmiş Milletler Suç ve Uyuşturucu Ofisi'nin (United Nations Office on Drus and Crime-UNODC) Orta Asya Bölgesel Bilgi ve Koordinasyon Merkezi ile iş birliği protokolü ${ }^{37}$ imzaladı. İki yapı, yasadışı uyuşturucu ticaretinin bölgedeki terör örgütleri için bir kaynak olarak kullanılmasına karşı mücadelede, iş birliğini geliştirmeye öncelik verdi.

Şï̈, geleneksel olmayan güvenlik sorunlarına verilen yanıtların koordinasyonunda, bir merkez olarak hareket etmeye odaklanmasina ve müdahaleci olmayan bir doktrin geliștirmesine rağmen, düzenli askerî tatbikatlara da devam etmektedir. ${ }^{38}$ Örgüt, daha önce düzenlediği birkaç ortak askerî tatbikatı takiben, "barış misyonu" olarak bilinen düzenli askerî tatbikatlara ilişkin bir anlaşma imzaladı ve üyelerin katılımlarıyla tatbikatlar gerçekleştirildi. 2007, 2009, 2010, 2012 ve 2013 'te gerçekleştirilen bu tatbikatlara, Rusya ve Çin birlikleri daha geniş katılım sağlarken, Kazakistan tatbikatlarda dikkate değer rol oynadı; Kırgızistan ve Tacikistan ise daha alt düzeyde sorumluluklar

\footnotetext{
36 "Rashiad Alimov: Fighting drug trafficing is among SCO's priorities", 2017/03/11, http://eng.sectsco.org/news/20170311/226233.html, (Erişim Tarihi: 10.5.2018)

${ }^{37}$ UNODC Press Release, "Shanghai Cooperation Organization sign agreement to boost international health, safety and security", 14 June 2011, https://www.unodc.org/ unodc/en/press/releases/2011/June/unodc-shanghai-cooperation-organization-sign-agree ment-to-boost-international-health-safety-and-security.html (Erişim Tarihi: 19.5.2018)

${ }^{38}$ Marcel de Haas, War Games of the Shanghai Cooperation, a.g.e., pp. 382-386.
}

301

Güvenlik Stratejileri

Cilt: 15

Sayı: 30 

bir katılıma karşı olduğundan) tatbikatlara katılmayı genellikle reddetmektedir. ${ }^{39} \mathrm{Bu}$ tatbikatların senaryoları, Orta Asya'daki mevcut bir rejime karşı silahlı ayaklanma gibi, "üç kötü güç" tarafindan yaratılan güvenlik sorunlarına verilen ortak yanıtları içermektedir. Barış Misyonu 2016, Kırgızistan’ın Issık Göl bölgesindeki Edelweiss dağcılık eğitim merkezinde gerçekleşti. Teröre karşı yeteneklerin geliştirilmesini amaçlayan tatbikata Çin, Kazakistan, Kırgızistan, Rusya ve Tacikistan Silahlı Kuvvetleri'nden yaklaşık 2000 personel katıldı. ${ }^{40}$ ŞİÖ Birleşik Gücü senaryolarının niteliği, ŞİÖ’nün bu tür güvenlik krizleri karşısında askerî olarak hareket edebilme kapasitesini geliştirip geliştiremeyeceği ya da barışı koruma gücü olarak rol oynayıp oynamayacağı tartışmalarını da gündeme taşımaktadır. ${ }^{41}$ Barış misyonlarının ana rolünün, genel olarak, ŞïÖ üyeleri arasında güven artırmak olduğu ${ }^{42}$ ifade edilebilir. Bununla birlikte, Rusya ve Çin'in, 2000'li yılların ortasından bu yana, askerî güçlerinin birlikte çalışabilirliğini artırmak için çalıştıklar1 ${ }^{43}$ da belirtilmelidir.

ŞİÖ; uluslararası bilgi güvenliğinin, uluslararası güvenlik sisteminin ana unsurlarından olduğunu ve bilgi teknolojilerine yönelik tehdit hakkında tedbir geliştirilmesi gerektiğini, iddia etmektedir. ${ }^{44}$ "Bilgi alanı" nın, siyasi istikrarı bozan bölge dışı aktörlerin sızmalarına engel olmak için güvenilir olması gerektiğini ileri süren ŞïÖ; terörizm, aşırıcılık ve bölücülüğü kışkırtan, ülkelerin ekonomik, sosyal ve siyasi istikrarı ile güvenliğini istikrarsızlaştırmaya yönelik bilginin yayılmasının

${ }^{39}$ Stephen Aris, Shanghai Cooperation, a.g.e., p. 6.

40 "SCO exercises Peace Mission-2016 completes in Kyrgyzstan", KABAR, http://old.kabar.kg/eng/society/full/17005 (Erişim Tarihi: 10.4.2018)

${ }^{41}$ Stephen Aris, Shanghai Cooperation, a.g.e., pp. 5-6.

${ }^{4}$ A.ge.

43 Vasily Kashin, Alexander Lukin, "Russian-Chinese Security Cooperation in Asia", Asian Politics \& Policy, Volume 10, Number 4, 614-632, p. 631.

44 Agreement on Cooperation in Ensuring International Information Security between the Member States of the Shanghai Cooperation Organization, Article 4. 
Şanghay İşbirliği Örgütü:

Çıkarlar/Öncelikler ve Bölgesel İş Birliği Arasında Bir Denge Arayışı

kısıtlanması gerektiğini savunmaktadır. ${ }^{45} \mathrm{Bu}$ konuda önemli bir gelişme, 2009'da Ekaterinburg'da sağlandı ve "ȘiÖ ülkeleri arasında Uluslararası Bilgi Güvenliğini Sağlamaya yönelik İş Birliği Anlaşması" imzaland $1{ }^{46} 2011$ 'de, "Uluslararası Bilgi Güvenliği Davranış Kuralları" çalışmasını Birleşmiş Milletlerin dikkatine sunan ŞīÖ, bu konuda güncellediği önerisini 9 Ocak 2015 'te tekrarladi. ${ }^{47}$

Sınırlarının kontrol edilememesi nedeniyle Afganistan, Orta Asya'da güvenliğin sağlanmasında daima önemli bir sorun olarak görülmektedir. Bundan dolayı ŞiÖ, Afganistan'a yönelik bölgesel bir yaklaşım geliştirmeye odaklanmış durumdadır. Buna ilişkin olarak, ŞİÖ-Afganistan Temas Grubu faaliyetleri hızlandırıldı ve Afganistan 2012'de ŞİÖ'de, gözlemci üye statüsü aldı. Afganistan Temas Grubu, yaklaşık yedi yıl aradan sonra, Rus Dışişleri Bakanlığı'nın ev sahipliğinde yeniden çalışmalarına başladı. ${ }^{48}$

2000'li yılların ortalarından itibaren, güvenliğin yanı sıra ekonomik iş birliği, ŞiÖ’nün bir başka önceliği olarak belirginleşti. 2004'te ŞïÖ eğitim, bilim, teknoloji, ulaştırma ve enerji ile ilgili 127 projeyi kapsayan çok taraflı ticaret ve ekonomik iş birliği programını açıkladı. ${ }^{49}$ Bir y1l sonra bu programın gerçekleştirilebilmesi için ŞïÖ Bankalararası Konsorsiyum ve ŞiÖ İş Konseyi tarafindan oluşturulan bir

\footnotetext{
45 A.g.e. Article 3.

${ }^{46}$ Agreement on Cooperation in Ensuring International Information Security between the Member States of the Shanghai Cooperation Organization.

47 "An Updated Draft of the Code of Conduct Distributed in the United NationsWhat's New?", 10 February 2015, CCDCOE NATO Cooperative Cyber Defence Centre of Excellence, https://ccdcoe.org/updated-draft-code-conduct-distributedunited-nations-whats-new.html, (Erișim Tarihi: 22.5.2018)

${ }^{48}$ Ministry of Foreign Affairs Islamic Republic of Afghanistan, "Shanghai Cooperation Organization (SCO) Afghanistan Contact Group Meeting", Oct 11, 2017, http://mfa.gov. af/en/news/shanghai-cooperation-organization-sco-afghanistan-contact-group-meeting, (Erişim Tarihi: 12.5.2018)

${ }^{49}$ Norling, Nicklas and Niklas Swanstrom, "The Shanghai Cooperation Organization, Trade, and the Roles of Iran, India, and Pakistan", Central Asian Survey, 26(3), September 2007, p. 432.
}

\section{3}

Güvenlik Stratejileri

Cilt: 15

Say1: 30 
304

Güvenlik Stratejileri

Cilt: 15

Sayı: 30

plan yayımlandi. Her iki kuruluş, koordinasyon merkezi olarak hizmet etmekte ve üye ülkeler tarafindan üzerinde anlaşmaya varılan projelerin yürürlüğe konulması doğrultusunda, ilgilileri teşvik etmektedir.

Bugüne kadar ekonomik iş birliği, devletlerin altyapısını geliştirmeye yönelik olarak özellikle ulaşım yollarına yoğunlaştı. Bu bağlamda ŞïÖ, Volgograd (Rusya), Astrakhan (Rusya), Atyrau (Kazakistan), Beyneu (Kazakistan) ve Kungrad (Özbekistan) arasında yol inşa etmeye yönelik projelerin geliştirilmesinde merkezî bir rol oynamaya çalışmaktadır. ${ }^{50}$ Andican (Özbekistan), Torugart (Kırgızistan) ve Kaşgar (Çin) arasındaki demiryolunun inşası ile ilgili görüşmeler ise devam etmektedir. ${ }^{51}$ Ulaşım altyapısı üzerine yapılan çalışmalarla bağlantılı olarak Şı̇Ö, Asya Kalkınma Bankası ve Birleşmiş Milletler Asya ve Pasifik Ekonomik ve Sosyal Komisyonu (The United Nations Economic and Socal Comission for Asia and the Pacific-ESCAP) ${ }^{52}$ ile de iş birliği içinde çalışmaktadır.

Büyük ölçekli ekonomik altyap1 projeleri üzerindeki yoğunlaşma, ŞīÖ'nün güvenlik ve ekonomiyi güçlü bir biçimde birbirine bağlı olarak konumlandırması nedeniyle şaşırtıcı değildir. Orta Asya cumhuriyetlerinden bazılar1, uluslararas1 sistemde, ekonomik açıdan en az gelişmiş devletlerarasında yer almaktadır ve altyapının geliştirilmesinde yabancı yatırımları çekme gayreti, bu ülkelerin önceliğidir. ${ }^{53}$ ŞīÖ’nün ekonomik gündemi bağlamında Çin, bu tür yatırımların en önemli kaynağı olarak görülmektedir. Özellikle, 2008/9 küresel mali krizin ardından ŞīÖ veya daha doğrusu Çin, Şiö üyelerine, ekonomilerini küresel ölçekte desteklemek için 10 milyar dolar tutarında kredi sağlamayı teklif etti. ${ }^{54}$ Çin'in 2004'te ŞiÖ üyelerine 900

${ }^{50}$ Julie Boland,'Ten Years of the Shanghai Cooperation Organization: A Lost Decade? A Partner for the U.S.?" $21^{\text {st }}$ Century Defense Initiative Policy Paper, 20 June 2011, p. 15.

${ }^{51}$ Stephen Aris, "Shanghai Cooperation Organization Mapping Multilateralism in Transition", International Peace Institute, No: 2, 2013, p. 6.

${ }^{52}$ Julie Boland, Ten Years, a.g.e., p. 15.

${ }^{53}$ Stephen Aris, Shanghai Cooperation, a.g.e., p. 7.

${ }^{54}$ Julie Boland, Ten Years, a.g.e., p. 15. 
Şanghay İşbirliği Örgütü:

Çıkarlar/Öncelikler ve Bölgesel İş Birliği Arasında Bir Denge Arayışı

milyon dolarlık krediyle yaptığı bir başka teklif, ŞiÖ’nün ekonomik boyutunda Çin'in etkisini ${ }^{55}$ açıklaması noktasında, dikkat çekmektedir. Üye ülkeler, önerilen kredileri aldıklarında, ekonomik karar alma süreçleri üzerinde Pekin'in siyasi egemenlik kazanacağından endişe etmektedir.

Şi̇Ö bünyesinde 2003'te belirlenen çok sayıda projenin uygulanması, son derece sınırlı kaldı. Bunun üzerine Şï̈, projeleri yürürlüğe koymanın hız ve etkinliğini artırmak için planlar hazırladı. Bunun önemli bir yansıması, 2013 yıllık zirvesinde tartışılan ve yakın gelecekte kurulması muhtemel görünen bir ȘïÖ Kalkınma Fonu'nun oluşturulmasıdır. ${ }^{56} \mathrm{Bu}$ düzenleme uyarınca, üye ülkeler ŞīÖ ortak projelerinin gerçekleştirilmesi için doğrudan Kalkınma Fonu'na kaynak tahsis edecektir.

Rusya Devlet Başkanı Vladimir Putin'in 2006 Zirvesi'nde, bir ŞiÖ enerji kulübü oluşturma önerisi, önemli bir ekonomik iş birliği girişimiydi. ${ }^{57}$ Enerji kulübü kavramı, Şiö üyeleri arasında bir iç enerji piyasası düzenlenmesini, enerji kaynakları ile boru hatlarını geliştirmek için ortak projeler oluşturmayı gerektirecektir. ŞïÖ üyelerinin, fiyat maksimumlaştırma ve arz güvenliği sağlanmasıyla ilgili üreticiler ile tüketiciler olarak farklı çıkar çatışmalarından dolayı, en azından yakın gelecekte resmî bir enerji kulübü kurulması ihtimalinin zayıf olduğu ${ }^{58}$ düşünülmektedir. Bununla birlikte, genel olarak enerji konusu, ŞïÖ için önemli bir iş birliği alanıdır. Bu bağlamda Geleceğin Enerjisi (Energy of Future) temalı EXPO-2017'nin, 100'den fazla ülkenin katılımıla 10 Haziran-10 Eylül 2017 tarihleri arasında Astana'da

\footnotetext{
55 Marlene Laruelle and Sebastien Peyrouse, The "Chinese Question" in Central Asia: Domestic Order, Social Changes, and the Chinese Factor, Hurst and Company, London 2012.

56 "Joint Communique, Twelfth meeting of the Council of Heads of Government (Prime Ministers) of the Member States of the Shanghai Cooperation Organization", Article 4.

57 "Russia's President Putin proposes SCO energy club", Media group/Tajihistan Asia-Plus, http://www.news.tj/en/news/russias-president-putin-proposes-sco-energy-club, June 15, 2006, (Erişim Tarihi: 1.6.2018)

${ }^{58}$ Stephen Aris, Shanghai Cooperation, a.g.e., p. 7.
}

\section{5}

Güvenlik Stratejileri

Cilt: 15

Say1: 30 
306

Güvenlik Stratejileri

Cilt: 15

Sayı: 30

düzenlendiğ $\mathrm{i}^{59}$ belirtilmelidir.

Çin yönetimi, tüketici endüstrilerine yönelik yeni pazarlar açılması için tarife engellerinin kaldırılmasını, ŞiÖ’nün birincil amaçlarından biri olarak görmekte ve 2010'dan itibaren ŞïÖ için serbest ticaret bölgesi önermektedir. ${ }^{60}$ Çin, uzun vadede gümrük birliği amaçlarını gerçekleştirmek için Orta Asya cumhuriyetlerinin gelişimine yatırım yapmanın gerekli olduğunu düşünmektedir. Bundan dolayı Çin, düzenli olarak, Orta Asya cumhuriyetlerine altyapılarını geliştirmelerine yönelik geniş çaplı krediler sağlamaktadır. ŞīÖ'nün diğer üyeleri, zayıf üyelerin ekonomik altyapısını geliştirme gündemini desteklerken, ticaret engellerini azaltmak konusunda, daha az isteklidir. ${ }^{61}$ Moskova ise, Orta Asya pazarına sınırsız erişimin olması halinde, Rusya'nın bölgesel ekonomideki yerinin tehdit edilebileceğini düşünmektedir. İlave olarak, Orta Asya liderleri, ucuz Çin mallarının ekonomilerine girmesi halinde, ülke ekonomileri üzerinde kontrol kaybı ihtimali olabileceğini, böyle bir senaryonun sosyo-ekonomik sorunlarla sonuçlanabileceğini değerlendirmektedir. ŞiÖ ülkelerinin yatırımcıları, Çinli tüccarlar tarafindan sunulan fiyatlarla rekabet gücüne sahip olmadıklarından, serbest ticareti hedefleyen Çin girişimleri, diğer ülkelerce benimsenmemektedir.

\subsubsection{Kültür}

Güvenlik ve ekonomi ana iş birliği alanları olmakla birlikte, son yıllarda Şiö bünyesinde farklı alanlarda da iş birliği girişimlerinin arttığına tanık olunmaktadır. Bu bağlamda üye ülkelerin halkları arasında daha fazla temas sağlanmasına yönelik olarak, bir dizi Şı̈Ö girişimi ve projesi geliştirildi. Projelerde ortak anlayış, karşıllklı güven

59 "Press release on the results of the Shanghai Cooperation Organisation Heads of State Council Meeting", Astana 8-9 June 2017.

${ }^{60}$ Alexander Gabuev, "Bigger, Not Better: Russia makes the SCO a Useless Club", Carnegie Moscow Center, 23.6.2017, https://carnegie.ru/commentary/71350 (Erişim Tarihi: 23.5.2018)

${ }^{61}$ A.g.m. 
Şanghay İşbirliği Örgütü:

Çıkarlar/Öncelikler ve Bölgesel İş Birliği Arasında Bir Denge Arayışı

ve bölge menfaati üzerinde durulmaktadır. Bu çabalar kapsamında, ortak eğitim standartlarının üye ülkeler arasında kabul edilmesini ve bir ŞiÖ Üniversitesi oluşturulmasını amaçlayan programlar açıklandı. ŞİÖ Üniversitesi master programı 2010'dan itibaren eğitim-öğretim faaliyetlerine başladı. ${ }^{62}$ Çin tarafından desteklenen ve diğer ŞïÖ ülkeleri öğrencilerine Çin'de eğitim bursu sağlayan bir program hâlen uygulanmaktadır. 2010'da Şanghay'daki World Expo'da ortak bir ŞïÖ sergisi düzenlendi. ŞiÖ'nün desteğiyle "Çocuklar Tarafından Yazılmış Masallar" adlı sanat sergisinde üye ülkelerin çocukları, diğer Şı̈̈ üye ülkelerini nasıl hayal ettiklerini çizdi. ${ }^{63}$ Benzer biçimde, Kazakistan'ın başkanlığ 1 döneminde, Astana' da 25-27 Nisan 2017 tarihleri arasında Eğitim Haftası, 6 Haziran 2017'de ŞïÖ ülkeleri Bilim İnsanları Sempozyumu, 7-11 Haziran 2017 tarihleri arasında Şiö Yeşil Ekonominin Geliştirilmesi, Turizm ve Spor etkinlikleri düzenlendi. ${ }^{64}$

\section{2. Şanghay İş Birliği Örgütü'nün Karşılaştığı Sorunlar}

Şi̇Ö; üye ülkelerin siyasi ve ekonomik sistemlerinin, diplomatik ve ekonomik güçlerinin, dinlerinin, kültürlerinin ve coğrafi farklılığının çeşitliliğini vurgulamaktadır. ŞïÖ, bu çeşitliliğin farkında olarak, "Şanghay Ruhu" olarak da anılan, bütün üyelerine yönelik yeni bir kapsayıcı bölgesel iş birliği modelini temsil ettiğini iddia etmektedir. Şiö, üye devletlerarasındaki ilişkileri iyileştirmek ve yönetmek için güven artırıcı önemli bir mekanizma olmasına rağmen, kuruluşun kapasitesi ve başarısı sorgulanmaktadır. Örgütün uzun dönemde sürdürülebilirliği ve etkinliği açısından; Şī̈ üyeleri arasındaki ilişkilerin en önemlisinin Rusya-Çin ilişkileri olduğu düşünülmektedir. ŞiÖ, son 20 yılda Rusya-Çin ilişkilerindeki sürekli iyileşmeye koşut olarak gelişti. $\mathrm{Bu}$ eğilime rağmen; uzun vadede, çıkar çatışmaları

62 "SCO University project: definitely successful", 08.06.2011, http://infoshos.ru/ en/?idn=8338 (Erişim Tarihi: 20.5 .2018)

${ }^{63}$ Stephen Aris, Shanghai Cooperation, a.g.e., p. 8.

64 "Press release on the results of the Shanghai Cooperation Organisation Heads of State Council Meeting", Astana 8-9 June 2017. 

nedeniyle Rusya-Çin ilişkilerinin bozulabileceğini öngören ${ }^{65}$ yaklaşımlar da mevcuttur.

Bazı analistler, ŞiÖ’nün bölgedeki iç güvenlik sorunlarına odaklandığını, özellikle üye ülkelerin elitlerinin, rejimlerinin güvenliğine karş1 ortaya çıkabilecek tehditleri ${ }^{66}$ bertaraf etmek için örgütü meşrulaştırıcı bir vasıta olarak kullandıklarını iddia etmektedir. Bu iddiaya göre, ŞïÖ, Orta Asya'daki demokratik gelişmeleri engelleyen uluslararası kurumsal bir yapıdır. Bir başka yaklaşıma göre ise, Çin, Sovyetler Birliği’nin dağılması üzerine ŞiöÖ vasıtasıyla çokuluslu bir yaklaşım çerçevesinde komşu bölgelere giriş yapmakta $;{ }^{67}$ Rusya ise, Çin'in bölgedeki etkinlik artırma girişimlerini örgüt bünyesinde kalarak engellemeye çalışmaktadır. Orta Asya ülkeleri ise; bölgesel güçler olan Çin ve Rusya'yı, Şı̈Ö içinde birbirine karşı sınırlamayı amaçlamaktadır. ${ }^{68}$

Çin ve Rusya'nın, ŞiöO'ye karşı yaklaşımları arasında farklılık olduğunu belirten görüşte olanlara göre, Rusya'nın ŞiÖ'ye karş1 ilgisi azalmakta $^{69}$ ve bu ülke, ŞiöÖ gündeminin yoğunlukla Çin tarafından domine edildiğini düşünmektedir. Bu bağlamda Moskova, özellikle, Çin'in serbest ticaret gündemini geliştirme yönündeki çabalarını kısıtlamayı ve bu alandaki iş birliğini Çin'in üye olmadığı bölgesel çerçevelerde tutmayı tercih etmektedir. Bu durum dikkate alındığında ŞİÖ'nün, her iki aktörün örgüte olan ilgisinin sürdürülebilmesi için gayret göstermesi gerektiğini vurgulamak gerekmektedir.

ŞïÖ, Orta Asya cumhuriyetleri için her iki bölgesel güçle eş zamanlı olarak iş birliğini geliştirebilecekleri bir forum oluşturmaktadır. ŞīÖ bünyesinde Rusya ve Çin'in varlığı, bu ülkeler tarafından, bölgede

${ }^{65}$ Bobo Lo, Axis of Convenience Moscow, Beijing and The New Geopolitics, Brookings Institution Press, Washington 2008.

${ }^{66}$ Roy Allison, Regionalism, regional structures, a.g.e., p. 482.

${ }^{67}$ Alexander Gabuev, Bigger, Not Better, a.g.m.

${ }^{68}$ Weiqing Song, "Interests, Power and China's Difficult Game in the Shangai Cooperation Organization (SCO)", Journal of Contemporary China, 23:85, 2014, 85-101, p. 86.

69 Joshua Kucera, "Russia "Increasingly Distrustful" Of SCO", Mar 5, 2013, https://eurasianet.org/s/russia-increasingly-distrustful-of-sco (Erişim Tarihi: 4.5.2018) 
Şanghay İşbirliği Örgütü:

Çıkarlar/Öncelikler ve Bölgesel İş Birliği Arasında Bir Denge Arayışı

gündemin tek bir egemen güç tarafindan domine edilmeyeceğinin garantisi olarak görülmektedir. Başka bir ifadeyle, Orta Asya ülkeleri, ŞiÖ’nün mevcut yapısı içinde kendi çıkarlarını takip etme firsatı bularak, sadece Rusya ya da Çin'i kapsayan bir çerçeveden daha fazla hareket serbestliğine sahip olabilmektedir. Bu durum, Rusya liderliğindeki bölgesel örgütlere olan karşı tutumu göz önünde bulundurulduğunda, Özbekistan'ın ŞīÖ'ye üye olmasının gerekçesini ${ }^{70}$ de açıklamaktadır. Özbekistan, 2000'lerin ortalarına kadar Kolektif Güvenlik Anlaşması Örgütü (Collective Security Treaty Organization-CSTO) ${ }^{71}$ ve Avrasya Ekonomik Topluluğu'na (Eurasian Economic Community-EurAsEC) ${ }^{72}$ katılmayı reddetti; daha sonra, katılımını müteakip her iki örgütten de çekildi. Özbekistan'ın bu örgütlerden çekilmesi ile ilgili kararının başlıca gerekçesi, her iki örgütte de var olan Rusya etkisidir. Özbekistan'ın Rusya'nın Orta Asya'ya yönelik askerî planlamalarına ve özellikle CSTO bünyesindeki Birleşik Ani Müdahale Gücü (Collective Rapid Reaction Forces-CRRF) oluşumuna da karși olduğu bilinmektedir. ${ }^{73}$

Orta Asya, son zamanlara kadar genel olarak tek bir varlık/bölge olarak nitelendirilmesine rağmen, Sovyetler Birliği’nin dağılmasından sonra, Orta Asya cumhuriyetleri arasında belirgin bir siyasi ve ekonomik boşluk oluştu. Bu devletlerin bazıları arasındaki ilişkilerdeki ana tema, iş birliğinden daha çok rekabettir. Bölgede sınırların belirlenmesi ve azınlık gruplarla ilgili gerginlikler, Sovyetler Birliği sonrasında önemli anlaşmazlık konuları olarak öne çıktı. Sınır belirlemesi ile ilgili gerginlik, Özbekistan ile Tacikistan ve Kırgızistan arasında daha belirgindir ve sınır çatışmalarına neden olmaktadır. Bir başka gerginlik kaynağı ise,

\footnotetext{
${ }^{70}$ Stephen Aris, Shanghai Cooperation, a.g.e., p. 9.

71 "Collective Security Treaty Organization (CSTO)", https://www.globalsecurity.org/ military/world/int/csto.htm (Erişim Tarihi: 3.5.2018)

72 "Eurasian Economic Community (EurAsEC), Rostechnadzor", http://en.gosnadzor.ru/ international/organizations/eurasec/ (Erişim Tarihi: 2.5.2018)

${ }^{73}$ Bernardo Teles Fazendeiro, , "Uzbekistan's Suspension of CSTO Membership: Policy as Usual in Tashkent",E-International Relations, Jul 19 2012, http://www.e-ir.info/ 2012/07/19/uzbekistans-suspension-of-csto-membership-policy-as-usual-in-tashkent/ (Erişim Tarihi: 7.5.2018)
}

\section{9}

Güvenlik Stratejileri

Cilt: 15

Say1: 30 
su kaynakları üzerinde kontrol sağlamayla ilgilidir. Orta Asya bölgesindeki ana su kaynakları, Kırgızistan ve Tacikistan'ın dağlık

Güvenlik Stratejileri

Cilt: 15

Say1: 30 bölgelerinden, Kazakistan, Türkmenistan ve Özbekistan nehirleri boyunca akmaktadır. Enerji üretmeye yönelik olarak, diğer doğal kaynaklardan yoksun olduklarından, memba ülkeleri, hidroelektrik enerji üretimi için baraj inşa etmeye odaklanmaktadır. Bu politika, güçlü bir su akıntısı ile sulanması gereken pamuk benzeri bitkilerin sulanmasinda sorunla karş1laş1lmasına neden olduğundan, millî gelirin önemli bir bölümünü tarımsal üretimden edinen aşağı mansap ülkeleri ile memba ülkeleri arasında çıkar çatışmasını da beraberinde getirmektedir. Bu bağlamda özellikle Özbekistan ve Tacikistan arasında gerginlik yaşanmaktadır. Taşkent'in, Tacik endüstrisinin bağlı olduğu doğal gaz kaynaklarını keserek verdiği tepkiye rağmen, Duşanbe, Rogun Barajı projesinde ilerlemeye çalışmaktadır. 2016' da başlanan baraj inşaatı projesinin, yaklaşı 12 yılda bitirilmesi öngörülmektedir. Rogun Barajı ile ülkenin enerji üretiminin iki katına çıkması beklenmektedir. ${ }^{74}$ ŞīÖ'nün, örgütün işlevselliğine zarar vermemesi için Orta Asya üyeleri arasındaki bu gerginlikleri yönetmede önemli rol oynaması gerekmektedir.

BM Güvenlik Konseyi'nde veto yetkisine ve ayrıca nükleer güce sahip Çin ve Rusya'nın da örgütün üyesi olması nedeniyle, Şiö, oluşumundan bu yana, bölgesel bir oyuncu olmanın yanı sira, küresel bir aktör olma potansiyeli ile de dikkat çekmektedir. Bununla birlikte, Ş่Ö'nün henüz çok güçlü bir yapıya dönüşmediği ${ }^{75}$ belirtilmelidir. ŞiÖ, üç kötülüğü engellemek için geliştirilen programlar ve mekanizmaların yanı sıra, üye devletlerin güvenlik politikaları için önemli bir meşrulaştırma rolü de oynamaktadır. Bu bağlamda, Şi̇Ö'nün bir siyasi işlevinin; koruyucu bütünleşmeyle sembolik olarak Orta Asya rejimlerine siyasal eşitlik ve yasallık sağlayan dayanışma olduğu hususu üzerinde durulmaktadır. Andican bölgesindeki halk hareketinin bastırılması esnasındaki uygulamalarından dolayı Batı tarafından ağır eleştirilere

74 "Rogun Hydropower Project", https://www.salini-impregilo.com/en/projects/inprogress/rogun-dam.html\#, (Erişim 25.5.2018)

${ }^{75}$ Stephen Aris, Shanghai Cooperation, a.g.e., p. 10. 
Şanghay İşbirliği Örgütü:

Çıkarlar/Öncelikler ve Bölgesel İş Birliği Arasında Bir Denge Arayışı

maruz kalan Kerimov rejimine, 2005'de y1llık zirvesini Özbekistan'da düzenleyerek verdiği destek, ŞİÖ'nün üye ülkelerin rejimlerini dış eleştirilere karşı korumasına yönelik bir örnek olarak gösterilebilir. $\mathrm{Bu}$ yöntemle ŞïÖ, insan haklarının evrenselliğinden ziyade yakınsallığı destekleme eğiliminde olarak; başkalarının, üye ülkelere dışarıdan değerler dayatması çabalarına direnen bir mekanizma ${ }^{76}$ olarak işlev görmektedir. ŞiÖ, bu uygulamayla ulusal egemenlik ve toprak bütünlüğü ilkelerinin önemini vurgulamaktadır. ŞïÖ, özellikle, üye hükümetlerin, uygun gördükleri güvenlik politikalarını takip etme hakkı olduğunu savunmaktadır. Evrenselliğe karşı bölgesel yakınlığı önceleyen tutumu, ${ }^{77}$ ŞiÖ'nün bölgedeki baskıcı uygulamaların savunucusu olarak eleştirilmesine yol açmaktadır.

\section{3. Şanghay İş Birliği Örgütü'nün Geleceği}

Şi̇Ö'nün gelecekteki yapısı ve faaliyet alanlarının, üye ülkeler tarafından nasıl şekillendirileceğine dair öngörüler, ŞiÖ Devlet Başkanları Konseyi’nin 12 Eylül 2014'te Duşanbe'de “2025 Yılına Kadar Şanghay İş Birliği Örgütü' nün Geliştirilmesi İçin Bir Taslak Strateji” başlıklı Üç Numaralı Kararı ile uyumlu olarak geliştirilen "Şanghay İş Birliği Örgütü'nün 2025 yılına kadarki Geliştirme Stratejisi” (Development Strategy of the Shangai Cooperation Organization until 2025) ${ }^{78}$ belgesinde yer almaktadir. Stratejide, üye devletlerin odaklanacakları hedefler belirlenmiştir. Bunlardan bazıları şu şekilde sıralanabilir:

- Şı̈Ö bölgesini barış, sürdürülebilir kalkınma, ekonomik büyüme ve ilerleme, karşılıklı güven, iyi komşuluk, dostluk ve refah alanına dönüştürmek;

- ŞİÖ’yü, askerî ve politik bir blok veya uluslarüstü yönetişim organları olan, bir ekonomik entegrasyon birliği olarak öngörmeyen çok formatlı bir bölgesel örgüt olarak geliştirmek;

\footnotetext{
${ }^{76}$ A.g.e

${ }^{77}$ Roy Allison, "Virtual regionalism, regional structures and regime security in Central Asia”, Central Asian Survey, Vol. 27, No. 2, June 2008, 185-202, p. 197.

${ }^{78}$ Development Strategy of the Shangai Cooperation Organization until 2025.
}

\section{1}

Güvenlik Stratejileri

Cilt: 15

Say1: 30 
312

Güvenlik Stratejileri

Cilt: 15

Sayı: 30

- Şi̇̈ içinde ticaret ve yatırım iş birliğinin devamlılığ için uygun koşullar yaratmak, ortak altyap1 projelerinin geliştirilmesi ve uygulanmasında Şiö İş Konseyi ve ŞïÖ Bankalararası Birliği ile iş birliğini güçlendirmek;

- ŞiÖ’ye üye devletlerin İpek Yolu Ekonomik Kuşak girişimi ${ }^{79}$ için ŞiÖ bölgesinde ekonomik iş birliğinin teşvik edilmesine yönelik ortak yaklaşımlar geliştirmek;

- BM ve diğer uluslararası ve bölgesel kuruluşlar ile konvansiyonel ve yeni ortaya çıkan güvenlik tehditlerinin ele alınmasında, bölünmeyen bir güvenlik alanı oluşturmak.

Strateji'de ŞīÖ bünyesindeki iş birliğinin karşılıklı güven, karş1lıklı yarar, eşitlik, karşılıklı danışma, kültürel çeşitliliğe saygı ve ortak kalkınma için isteklilik ruhu ile öne çıktığı belirtilmekte ve Şanghay Ruhu ${ }^{80}$ olarak bilinen bu ilkelerin, gelecekte de sürdürüleceği vurgulanmaktadır. Strateji'de, üye ülkeler, herhangi bir şï̈ üyesi ülkeye yönelik ittifaka veya örgüte ya da herhangi bir üye ülkeye karş1 düşmanca bir eyleme katılmayacakları konusunda mutabık kalmıştır. Üye ülkeler, kendi topraklarını, devlet egemenliğine ve toprak bütünlüğüne sayg1 ilkelerine aykırı herhangi bir faaliyet için kullandıramaz. ŞïÖ, "devletlerin içişlerine müdahalede bulunulmaması" prensibini benimsemekte ve herhangi bir devlete karşı BM Güvenlik Konseyi'nin onayı olmaksızın, tek taraflı yaptırım önlemlerinin kullanılmasinı desteklememektedir.

ŞīÖ, BM'nin koordine edici merkezî rolünü esas alarak, uluslararası hukukun üstünlügüne ve karşıllklı saygıya, içişlerine

${ }^{79} 2013$ 'de Çin'in önerdiği İpek Yolu Ekonomik Kuşak girişimi iddialı bir vizyon olarak dikkat çekmektedir. Bu girişimle proje kapsamındaki ülkelerin altyapılarının geliştirilmesi, bağlantılarının güçlendirilmesi ve Avrasya kıtasındaki ekonomik entegrasyon teşvik edilmektedir. Richard Ghiasy and Jiayi Zhou, "The Silk Road Economic Belt: Considering security implications and EU-China cooperation prospects", SIPRI, February, 2017, https://www.sipri.org/publications/2017/other-publications/silk-road-economic-belt (Erişim Tarihi: 2.6.2018)

${ }^{80}$ Development Strategy, a.g.e., Principles and Values. 
Şanghay İşbirliği Örgütü:

Çıkarlar/Öncelikler ve Bölgesel İş Birliği Arasında Bir Denge Arayışı

müdahale edilmemesine, güven ve faydaya, ülkeler arasında eşitlik ve ortaklığa dayalı demokratik adil ve rasyonel bir dünya düzeni oluşturmaya katkıda bulunmaya devam edeceğini, stratejisinde taahhüt etmektedir. İlave olarak ŞïÖ, tüm devletlerin meşru çıkarlarını göz önünde bulunduran etkili bir küresel ve bölgesel güvenlik mimarisi oluşturmaya yoğunlaşmayı ve barışç1l çözüm ve uluslararası çatışmaların önlenmesinde iş birliğini güçlendirmeyi hedeflemektedir.

Bölgesel güvenlik ve istikrarın sağlanmasına yönelik ŞïÖ'nün öncelikleri, terörizm, ayrılıkçılık, aşırılık; uyuşturucu; silah, mühimmat ve patlayıcı maddeler, nükleer ve radyoaktif materyaller; uluslararası organize suçlar ve uluslararası bilgi güvenliğine karşı faaliyetler; sınır güvenliğine yönelik tehditler, yasadışı göç ve insan kaçakçıllğı; kara para aklama, ekonomik suçlar ve yolsuzlukla mücadeledir. Strateji kapsamında, üye ülkeler düzenli olarak bu konular hakkında bilgi alışverişinde bulunacak ve bölgedeki durumun ortak analizini yaparak yetkili makamların katılımıyla iki taraflı ve çok taraflı eğitim, araştırma ve uygulamaya yönelik önlemler alacaktır. Bölgede barışı, güvenliği ve istikrarı tehdit eden durumlara karşı, Şiö, siyasi ve diplomatik önlemler ve mekanizmaların etkin kullanımı da dâhil olmak üzere, ortaya çıkan güçlüklere ve tehditlere yönelik süratli yanıt verme mekanizmasını geliştirmeye önem verecektir. Bu maksatla, üye devletler, aşırılıkla mücadele konusunda, bir ŞiÖ Sözleşmesi geliştirecek; kolluk güçleri arasındaki koordinasyonun geliştirilmesinin yanı sıra, eğitim kurumları, kitle iletişim araçları, araştırma merkezleri, dinî örgütler ve sivil toplum örgütlerinin çabalarını birleştirmeye özen gösterecektir. Üye devletler ayrıca internet yönetimi alanında iş birliğini geliştirecek, internetin bölgedeki barış ve istikrarı ortadan kaldırmaya yönelik kullanılmasının önüne geçecektir. Terörist amaçlar için bilgi ve iletişim teknolojilerinin kullanımıyla mücadelede ve Şiö ülkelerinin güvenliğine yönelik siber tehditlere karşı, mücadelede iş birliği mekanizmaları geliştirilecektir.

Şiö Kalkınma Fonu ve ŞiÖ Kalkınma Bankası'nı kurmaya yönelik çabalarını sürdürecek olan üye ülkelerin yenilenebilir ve alternatif enerji dâhil olmak üzere, enerji sektöründe çok yönlü iş birliği geliştirmeleri, stratejide vurgulanan bir başka konudur. Kültür alanında ise ŞīÖ üyesi ülkeler, hükümetleri arasında 2007 yılında imzalanan 
314

Güvenlik Stratejileri

Cilt: 15

Sayı: 30

"Kültür İ̧̧ Birliği ile ilgili Anlaşma" hükümlerinin uygulanmasına çaba sarf edecektir. Bu çerçevede, ŞiOO ülkeleri, çok etnikli ve çok dinli toplumlar olarak, yüzyıllardır farklı milletlerin ve dinlerin uyum içinde bir arada yaşama geleneklerini ön plana çıkarararak etnik gruplar arası ve dinlerarası barışı sağlamayı, güçlendirmeyi ve medeniyetler arasındaki diyaloğu ilerletmeyi öngörmektedir.

Şiö, günümüzdeki uluslararası ilişkileri şekillendiren ve yönlendiren normlar üzerinde, Batı ile yaşadığı gerginliklere ve Batı'nın Avrasya'daki karşıt müdahaleleri olarak nitelendirdiği uygulamalarına yönelttiği eleştirilere rağmen, Batı ile ortak çıkar alanları da belirlemektedir. Bunlardan en önemlisi; küresel düzeyde terörle mücadele, Afganistan ve çevresinde devam eden güvensizlik ve uyuşturucu kaçakçılı̆̆ını engellemeye yönelik çabalar konusunda, Batı ile daha fazla is birliği yapma potansiyelinin olduğunu vurgulamasıdır. Bu nedenle ŞiöÖ, Batı ile jeopolitik ilişkisinde iki yönlü bir yaklaşım geliştirmiştir: ${ }^{81}$

- Kendi bölgesel yetki alanını göz önünde bulundurarak, kullanabileceği alanı Batı'ya kapatmaya veya sınırlandırmaya çalışmakta;

- Avrasya'nın ötesindeki konularla ilgili olarak, Batı ile iş birliği için alan açmak istemektedir.

ŞİÖ'nün öngördüğü politik, ekonomik ve güvenlik iş birliği, üye ülkelerin tamamına fayda sağladığından, örgütün varoluş esnekliği yüksektir, ${ }^{82}$ ancak ŞiÖ üyelerinin örgütteki öncelikleri ve çıkarları arasında da asimetrik bir ilişki bulunmaktadır. Üye ülkelerden Çin ve Rusya'nın birbirine yakın güç ve etki yaratma kapasitesi örgütün çalışmalarını karmaşık hale getirmektedir. Gerçekte ŞīÖ, Kerr ve Swinton'un da belirttiği gibi, bölgesel istikrar, radikalizm karşıtlığı, enerji güvenliği ve dış etkiye karşı tutum geliştirmeyi de içine alan birden

${ }^{81}$ Stephen Aris, Shanghai Cooperation, a.g.e., p.10.

${ }^{82}$ Stephen Aris (2009), "The Shanghai Cooperation Organisation: 'Tackling the Three Evils'. A Regional Response to Nontraditional Security Challenges or an Anti-Western Bloc?" Europe-Asia Studies, 61:3, 457-482 p. 479. 
Şanghay İşbirliği Örgütü:

Çıkarlar/Öncelikler ve Bölgesel İş Birliği Arasında Bir Denge Arayışı

fazla amaca yönelik olarak kurulmuş uluslararası bir organizasyondur. ${ }^{83}$

Şi̇̈, uluslararası sistemi oluşturan yapıların birbirine daha çok bağımlı hale geldiği ve BM'nin bu değişen uluslararası sistemde merkezî bir rol oynaması gerektiği üzerinde durmakta, mevcut sorunlara etkili çözümler bulunabilmesi için, bu kuruluşun yeniden düzenlenmesi ${ }^{84}$ Güvenlik Stratejileri

Cilt: 15 gerektiğini savunmaktadır. ŞïÖ, Batı ile olan ilişkisinin ötesinde, aktif olarak bir dizi aktörle ilişkiler geliştirmektedir. Güneydoğu Asya Ülkeleri Birliği (Association of Souteast Asian Nations-ASEAN), ${ }^{85}$ Bağımsız Devletler Topluluğu (Commonwealth of Independent States$C I S)^{86}$ ve ESCAP ile ilgili mutabakat muhtıraları ${ }^{87}$ imzalanmış; 2010 ' da imzalanan "Şiö/BM Sekreteryası İş Birliği Ortak Bildirgesi" 88 ile fonksiyonel ilişkiler geliştirilmesine yönelinmiştir. ŞïÖ, uluslararası sistemde, Avrasya'yı küresel düzeyde temsil etme rolünü de üstlenmeye çalışmaktadır. Hâlen baskın bölgesel güç merkezi haline gelemeyen ŞīÖ, belirlediği konularda bölgesel iş birliği için bir forum ve ortak jeopolitik bakış açısı için bir platform olmaya öncelik vermektedir.

${ }^{83}$ David Kerr and Laura Swinton, "China, Xinjiang, and the transnational security of Central Asia", Critical Asian Studies 40 (1), (2008), p. 113.

84 "Declaration by the Heads of the Member States of theShanghai Cooperation Organization", Article IV.

85 "Memorandum of Understanding between the Secretariat of the Association of Southest Asian Nations (Asean Secretariat) And the Secretariat of the Shanghai Cooperation Organization (SCO Secretariat)", Jakarta, April 21, 2005.

86 "The memorandum of understanding between the Secretariat of the Collective Security Treaty Organization and the Secretariat of the Shanghai Cooperation Organization", Dushanbe, October 5, 2007.

${ }^{87}$ The Shanghai Cooperation Organization, "The SCO and ESCAP: Cooperation prospects", http://eng.sectsco.org/news/20170512/267457.html (Erişim Tarihi: 12.5.2018)

88 "Cooperation Between UN, Shanghai Cooperation Organization Dynamically Expanding, in Shared Quest for Peace, Prosperity, Says Secretary-General, in Message" SG/SM/12953, 11 June 2010, https://www.un.org/press/en/2010/sgsm12953.doc.htm 
Tablo: ŞĩÖ'ye Üye Ülkelerin Verileri (2016 yılı esas alınmıştır).

Güvenlik Stratejileri

Cilt: 15

Sayı: 30

\begin{tabular}{|c|c|c|c|c|c|}
\hline Ülke & $\begin{array}{c}\text { Nüfusu } \\
\text { (Milyon) }\end{array}$ & $\begin{array}{c}\text { Yüzölçümü } \\
\left(1000 \mathrm{Km}^{2}\right)\end{array}$ & $\begin{array}{c}\text { GSMH } \\
\text { (ABD Doları) } \\
\text { (Milyon) }\end{array}$ & $\begin{array}{c}\text { Askerî } \\
\text { Harcamalarının } \\
\text { GSMH'ya } \\
\text { Oran1 (\%) }\end{array}$ & $\begin{array}{c}\text { Toplam } \\
\text { Borcunun } \\
\text { Gelirine } \\
\text { oran1 (\%) }\end{array}$ \\
\hline Çin & $1.378,67$ & $9.596,961$ & $11.199,15$ & 1,9 & 5,3 \\
\hline Hindistan & $1.324,17$ & $3.287,3$ & 2.264 & 2,5 & 17,3 \\
\hline İran & 80,28 & $1.745,2$ & 418,98 & 3,0 & 2,7 \\
\hline Kazakistan & 17,79 & $2.724,9$ & 137,28 & 0,8 & 44,3 \\
\hline Kırgizistan & 6,08 & 199,9 & 6,55 & 3,2 & 7.876 \\
\hline Rusya & 144,34 & $17.098,3$ & $1.283,16$ & 5,4 & 19,2 \\
\hline Özbekistan & 31,85 & 447,4 & 67,22 & Bilinmiyor & Bilinmiyor \\
\hline Tacikistan & 8,73 & 141,4 & 6,95 & 1,2 & 28,1 \\
\hline
\end{tabular}

Kaynak: The World Bank, Countries and Economies, https://data.worldbank.org/country.

Şi̇Ö'nün kuruluşundan bu yana karşılaştı̆̆ en büyük sorun, açıkladığı iş birliği programlarını etkin şekilde uygulayıp uygulayamayacağı ile ilgilidir. ŞïÖ, siyasal söylemlerin uyumlaştırılamamaması ve açıklanan programların uygulamaya dönüştürülmemesi ile karakterize edilmektedir. Bu duruma bir örnek olması noktasında, Şı̈Ö'nün 2007'deki bütçesinin sadece 3,7 milyon dolar olmasının, ${ }^{89}$ belirlenen projelerin gerçekleştirilebilmesinin önündeki en önemli engel olduğuna dikkat çekilmektedir. Bir bakış açısına göre bu durum; ŞïÖ üyesi ülkelerin siyasi liderlerinin gündemi belirlediği ve anlaşmaların uygulamalarını denetlediği katı devletlerarası yönetişim sistemine sahip olunmasından kaynaklanmaktadır. Şiö organları, oylama olmaksızın karar almaktadır. Karar alma sürecinde bir üyenin itirazının olmaması, o üyenin kararı

89 Henry Plater-Zyberk and Andrew Monaghan, "Strategic Implications of the Evolving Shanghai Cooperation Organization", United States Army War College Press SSI, 2014, p. 28. 
Şanghay İşbirliği Örgütü:

Çıkarlar/Öncelikler ve Bölgesel İş Birliği Arasında Bir Denge Arayışı

kabul ettiği anlamına gelmektedir. ${ }^{90} \mathrm{Bu}$ ulusüstü otorite eksikliği, ŞïÖ'nün uygulayıcı bir aktör olarak hızını ve etkinliğini kısıtlamaktadır.

Üye devletler arasında ikili veya üçlü anlaşmalarla ortaya konulan bir dizi proje, ŞïÖ projesi olarak ifade edilmesine rağmen, ŞiÖ’nün bu projelerin gelişmesinde çok az rolü olabilmektedir. Bir ya da daha fazla ülkenin herhangi bir projeye katılmaması, diğer ülkeler tarafindan o projenin yürütülmesine engel teşkil etmemektedir. Şiö üyelerinin ekonomik çıkarları, belirli sektörlerde birbiriyle uyumlu değildir. Çin'in güçlü yapısından, Kırgızistan ve Tacikistan'ın güçlük içindeki ekonomilerine kadar, ekonomik kapasitelerde önemli farklılıklar bulunmaktadır. Çin, bölgede serbest ticaretin savunuculuğunu yaparken, diğer bazı üye ülkeler, ekonomilerinin sıkı politik kontrolünü istememektedir. Ayrıca, Çin'in üye ülkelerin büyük altyapı geliştirme projelerine fon sağlaması politik açıdan tartışmalı bir durum yaratmaktadır.

Ş่̇̈’nün önemli bir boyutu, güvenlik olmasına rağmen bu rolün doğası hem karışıklık, hem de anlaşmazlık konusudur. Bu konuyla ilgili ilk soru, ŞïÖ'nün güvenlik krizlerine yerinde müdahale etmesi gerekip gerekmediği üzerinde yoğunlaşmaktadır. Şı̈Ö, uzun süredir doğrudan bir güvenlik uygulayıcısı ya da barışı koruma gücü olarak değil; istihbarat toplanması, tehdidin tanımlanması ve uygulamaların uyumlaştırılmasına yönelik bir merkez olarak, müdahale içermeyen ${ }^{91}$ bir doktrin benimsedi. Bu bağlamda ŞïÖ’nün bir güvenlik sağlayıcısı olarak, Haziran 2010'da, Osh ayaklanmaları sırasında eyleme geçmemesi, eleştirilere yol açtı. ŞïÖ, Kırgız geçici hükümetinin kentteki şiddet içeren durumu ve çevresini kontrol altında tutmak için dış müdahale yardım talebine rağmen, müdahale etmeyi reddetti. Osh ayaklanmaları, görevdeki rejime acil bir beka sorunu yaratmadığından, ŞïÖ'nün yanıtı "müdahaleci olmayan politikasına ve devlet/rejim güvenliğine bağlılığı"

\footnotetext{
90 "Charter of the Shanghai Cooperation Organization", Article 16 Decisions-Taking Procedure.

91 Richard Weitz, "What happened to the SCO?" the Diplomat, May 17, 2010, https://thediplomat.com/2010/05/whats-happened-to-the-sco/ (Erişim Tarihi: 5.5.2018)
} 
içeriyordu. $^{92}$ Rejim-devlet güvenliğine bir beka tehdidi oluştuğunda, ŞiÖ’nün üye devletlerdeki durumlara nasıl tepki vereceği belli değildir.

ŞİÖ’nün gelişimini şekillendiren bir başka önemli faktör, üyelerinin birçoğunun aynı coğrafya ve iş birliği alanlarını kapsayan diğer bölgesel örgütlerin bir parçası olmasıdır. CSTO öncelikli olarak askerî ve güvenlik iş birliğine; EurAsEC ise ekonomik iş birliğine yoğunlaşmıştır. Tek Ekonomik Alan (Single Economic Space-SES), 2015'den itibaren Avrasya Birliği olarak, gümrük birliği niteliğindedir. CSTO ve EurAsEC, dört ŞiÖ üye ülkesinin yanı sıra, Ermenistan ve Beyaz Rusya'yı; Avrasya Birliği (Eurasian Union) ise, iki ŞīO üyesi olan Rusya ve Kazakistan'a ilave olarak Beyaz Rusya'yı kapsamaktadır. ŞïÖ'nün, her iki ana iş birliği alanındaki faaliyetlerini genişletme yaklaşımı, bu yapılarla sınırlandırılmış görünmektedir. CSTO, sahip olduğu Toplu Operasyonel Reaksiyon Gücü (Collective Operational Reaction Force $)^{93}$ ile bir güvenlik sağlayıcısı olarak, ŞiOÖ'den daha aktif bir rol oynamaya yatkındır.

Moskova, ŞiÖ'nün Rusya'nın Orta Asya'daki etkisini Çin'e karş1 kaybedeceği bir format haline gelmesinden çekinmektedir. Bundan dolayı, Rusya, daha fazla nüfuza sahip olduğu Sovyet sonras1 çevrede çok yönlü entegrasyona olanak sağlayan alanlarda, politik irade göstermektedir. Benzer biçimde, Orta Asya üyeleri de, askerî ve ticari iş birliğini son derece hassas alanlar olarak gördüklerinden, genel olarak Çin'e nazaran daha yakından bildikleri Rusya ile bu alanlarda iş birliğini geliştirmektedir. Bununla birlikte, aynı zamanda, Rusya önderliğindeki bölgesel mekanizmaların, çıkarlarına ve politika seçeneklerine zarar verecek biçimde Rusya'ya aşırı bağımlılı̆̆ının da farkındadır. Orta Asya ülkeleri perspektifinden bakıldığında, bu örgütlerin paralel varoluşları, tek bir örgütte aşırı güç yoğunluğuna karş1, bölgesel dengeleri sürdürmeye olanak sağlamaktadır. Çin ise,

${ }^{92}$ Stephen Aris, "The Response of the Shanghai Cooperation Organisation to the Crisis in Kyrgyzstan”, Civil Wars, 14, No. 3, 2012, 451-476, p. 456.

93 "Collective Security Treaty Organization (CSTO), Collective Rapid Reaction Forces", https://www.globalsecurity.org/military/world/int/csto.htm (Erişim Tarihi: 27.5.2018) 
Şanghay İşbirliği Örgütü:

Çıkarlar/Öncelikler ve Bölgesel İş Birliği Arasında Bir Denge Arayışı

2014'te Şanghay'da düzenlenen Asya'da “Etkileşim ve Güven Artırıcı Önlemler Konferansı"nda (Conference on Interaction and ConfidenceBuilding Measures in Asia-CICA) bölge dışı aktörlerin bölgeye etkilerinin önlenmesine yönelik bir yaklaşım benimsediğini gösterdi. "Yeni Asya Güvenlik Konsepti" olarak çerçevesi çizilen zirvede Çin Devlet Başkanı Xi Jinping, Asya merkezli sorunların, Asyalılar tarafindan çözülmesi gerektiğini vurguladı. ${ }^{94}$ Çin, böylece, ABD’nin egemen olduğu tek kutuplu dünya düzeninin aksine, bölgede daha eşit bir uluslararası düzenin gelişmesine katkıda bulunan bir kimliğ ${ }^{95}$ öne çıkarmaya özen göstermektedir.

2005 'te Hindistan, İran ve Pakistan'a gözlemci statüsünün verilmesinden bu yana, olası üyelik genişlemesine ilişkin olarak, ŞiÖ üyesi ülkeler arasında farklı görüşler bulunmaktadır. Bu konuda istekli olanlar; büyük ve küçük devletlerin, tedarikçilerin ve tüketicilerin, üreticilerin ve müşterilerin, modern ve geleneksel ticaret ortaklarının bir araya getirilmesiyle çok büyük bir ekonomik çerçeve oluşturulmasını yararlı görmektedir. Bu görüşe göre, Orta Asya ve Güney Asya'yı daha yakınlaştıracak, ticaret ve ekonomik iş birliği için yeni pazarlar açacak büyük ulaşım projeleri gerçekleştirilebilir. Diğer yandan, üye ülkeler, ABD ile sorunlu ilişkileri olan devletlerin ŞIOÖ üyeliğine ihtiyatlı yaklaşmakta; bu ülkelerin Şiö üyesi olmasının, Batı ile ikili ilişkileri ve uluslararası kuruluşların ŞïÖ algısını olumsuz yönde etkileyebileceğini düşünmektedir. $\mathrm{Bu}$ çerçevede, $\mathrm{BM}$ yaptırımlarına maruz kalan ülkelerin örgüt üyeliği dışında tutulmasına ilişkin kriterin geliştirildiği 2010 Zirvesi'nin, İran'ın örgüte üye olmasını engellediğ $i^{96}$ görülmektedir.

Orta Asya ülkeleri, genişlemeye belki de Rusya ve Çin'den daha katı biçimde karşı çıkmaktadır. Bu ülkeler, genişlemenin, ŞïÖ’nün odağını Orta Asya'dan Güney Asya'ya kaydıracağını düşünmektedir.

\footnotetext{
${ }^{94}$ Jing Don Yuan, "Beijing's institutional-balancing strategies: rationales, implementation and efficacy", Australian Journal of International Affairs, 2018, s.10.

${ }^{95}$ A.g.e.

96 "Regulation on Admission of New Members to Shanghai Cooperation Organization", 1.2 of General Provisions.
}

\section{9}

Güvenlik Stratejileri

Cilt: 15

Say1: 30 
$\mathrm{Bu}$ konuda, Çin ile Rusya arasında da belirgin bir yaklaşım farkı vardır: Çin, Asya'daki nüfuzunu artırmak ve Güney Asya'da pazar

Güvenlik Stratejileri

Cilt: 15

Say1: 30 firsatları yaratmak için daha geniş bir diş politika hedefinin bir parçası olarak, üyeliği genişletme konusunda istekli görünmektedir. Çin'in bu yaklaşımına karşıt olarak, Rusya ve Orta Asya ülkeleri ise, Asya'nın geri kalanıyla büyük ölçekli ekonomik ilişkiler ve bağlar kurma kapasitesine sahip olduklarını düşünmemektedir.

ŞïÖ’nün, bölgeyle uluslararası sistem arasındaki ilişkileri müzakere etme girişimleri, örgütün gelecekteki rolüne ilişkin ipuçları vermektedir. 2017 zirvesinde de görüldügü üzere, devam eden Suriye kriziyle ilgili ortak bir tavır sergilemesi, ${ }^{97}$ ŞİÖ'nün, uluslararası konularda ortak meselelerin tartışıldığı bir forum haline geldiğini göstermektedir. Ayrıca, ŞïÖ-Afganistan Temas Grubu çalışmaları noktasında, örgüt, Afganistan'ın geleceğinin tartışıldığ güvenlik, istikrar ve refahın sağlanmasında, Afganistan hükümetinin çabalarını desteklemektedir. ${ }^{98}$ Şi̇Önün Ukrayna'daki gelişmeleri ve İran'ın nükleer programını gündemine almas $1,{ }^{99}$ bölgesindeki uluslararası sorunlara karşı ilgisini gösteren, öne çıkan diğer gelişmelerdir.

Şi̇Ö'nün etki yaratma kapasitesini, sadece kendi bünyesindeki gelişmelerle değerlendirmek yeterli olmayabilir. Soğuk Savaş sonrasında artan bölgeselleşmenin bir parçası olarak kurulan diğer uluslararası örgütlerle birlikte değerlendirildiğinde, ŞïÖ’nün daha kapsamlı etki yaratma potansiyeline sahip olabileceği belirtilmelidir. BRICS (Brazil, Russia, India, China, South Africa) ve Şİ̈ gibi uluslararası yapıların ortaya çıkışı, Avrasya Ekonomik Birliği ile Çin İpek Yolu Ekonomik Kuşağı girişimi ve bunlar arasında sağlanabilecek koordinasyon, Büyük Avrasya veya Avrasya ortaklığı fikrinin ortaya çıkmasına yol açmıştır. ${ }^{100}$

97 "The Astana declaration of the Heads of State of the Shanghai Cooperation Organization", June 9, 2017

98 "Joint Communique following the 16th Meeting of the SCO Heads of Government Council”, December 2017.

${ }_{99}$ A.g.e.

${ }^{100}$ Alexander Lukin, "Russian-Chinese Cooperation in Central Asia and the Idea of Greater 
Şanghay İşbirliği Örgütü:

Çıkarlar/Öncelikler ve Bölgesel İş Birliği Arasında Bir Denge Arayışı

Putin'in Çin'i ziyareti sırasında Haziran 2016'da imzalanan Rusya-Çin Deklarasyonunda bu yaklaşım açıkça görülmektedir. Deklarasyonda Avrasya Ekonomik Birliği (Eurasian Economic Union-EAEU), ŞïÖ ve ASEAN üye ülkelerinin katılımı ile kapsamlı bir Avrasya ortaklığı oluşturulması ${ }^{101}$ çağrısında bulunulmaktadır.

\section{1}

Güvenlik Stratejileri

Cilt: 15

Say1: 30

Rusya ve Çin arasında gelişen ilişkiler; farklılıklar olsa da, genel olarak, ortak çıkarlara ve uluslararası sistemle ilgili ortak görüşe sahip olmalarına dayanmaktadır. Bu ilişki; 1980'lerin sonlarında yakınlaşma, 1990'ların ortalarında stratejik ortaklık ve 2001'de Dostluk Anlaşması'nın imzalanması ile iş birliğinde ilerleme ${ }^{102}$ olarak tanımlanabilir. Geçen on yıl içinde Rusya'nın Batı ile artan gerilimi ve Çin'in yükselişinden kaynaklanan sürtünme, Rusya ve Çin arasında oluşan uyumun güçlenmesine yardımcı oldu. ${ }^{103} \mathrm{Bu}$ uyum, ikili ilişkileri kurumsallaştıran, geçici düzenlemelerin ötesine taşıyan bir dizi anlaşma ile desteklendi. Rusya ve Çin arasında 1992-2014 yıllarında 154 ikili anlaşma, ${ }^{104}$ Şanghay İş Birliği Örgütü kapsamında ise 2001-2014 yılları arasında 54 anlaşma imzalandı. ${ }^{105}$ Anlaşmaların sayısı ve kapsamındaki artış, sadece potansiyel olarak olası ortak sorunları birlikte çözmek isteğini yansıtmamakta, iki ülke arasında gelişen iş birliğinin ulaştığı seviyeyi de ortaya koymaktadır.

\section{Sonuç ve Tartışma}

Sovyetler Birliği’nin dağılmasından sonra, Orta Asya'da oluşan siyasi boşlukta Rusya, Sovyetler Birliği'nin ardılı olarak uluslararası toplumda yerini alırken; Kazakistan, Kırgızistan, Özbekistan ve Tacikistan bölgenin yeni bağımsız devletleri olarak ortaya çıktı. Bu

\footnotetext{
Eurasia", India Quarterly 1-14, Indian Council of World Affairs (ICWA) 2019, p. 1.

${ }^{101}$ A.g.e., p. 9.

102 Thomas Ambrosio, "The Architecture of Alignment: The Russia-China Relationship and International Agreements", Europe-Asia Studies, 69:1, 2017, 110-156, s. 135.

${ }^{103}$ A.g.e.

${ }^{104}$ A.g.e. s. 120.

${ }^{105}$ A.g.e. s. 118.
} 
322

Güvenlik Stratejileri

Cilt: 15

Sayı: 30 dönemde iç istikrarın sağlanması, bağımsızlı̆ıın güçlendirilmesi, sınırların tespiti, komşu ülkelerle egemen devletler olarak ilişkilerin kurulması ve geliştirilmesi, Orta Asya' daki yeni bağımsız devletlerin önceliklerinin ön sıralarında yer aldı.

Kazakistan, Kırgızistan ve Tacikistan'ın Çin'le başlattıkları görüşmelere Rusya'nın da katılması ile tarihî Sovyet-Çin sınırında süregelen tartışmaların kısa sayılabilecek sürede çözüme kavuşturulması, bölgedeki istikrarın artmasına önemli katkı sağladı. Güven artırıcı bu gelişme ile birlikte, 1996'da, "Şanghay Beşlisi”" olarak bilinen mekanizma çerçevesinde, bölge ülkelerinin aralarındaki ilişkilerin güçlendirilmesi amaçlandı. Devam eden süreçte, Özbekistan'ın 2001'deki katılımıyla bölgedeki ülkeler arasında karşılıklı güvenin artırılması, iyi komşuluk ilişkilerinin ve kapsamlı iş birliğinin geliştirilmesi konularında mutabakat sağlandı. Böylece ŞïÖ, bağımsızlıklarını yeni kazanan bölge ülkelerinin yönetimlerinin meşruiyetlerini güçlendirmelerinde, siyasal eşitlik ve yasallık sağlayan uluslararası bir platform görevi üstlendi.

Bölgesel uluslararası bir kuruluş olarak kurulan şiö’ye üye ülkeler arasındaki çıkar ve önceliklerden kaynaklanan sorunlar ve beraberindeki rekabet ortamı, geçen süreç içerisinde gün yüzüne çıktı. Özbekistan ile Tacikistan ve Kırgızistan arasındaki sınır anlaşmazlıkları çatışmalara neden olurken, su kaynaklarının kontrolü ve kullanımından kaynaklanan sorunlar, Özbekistan ve Tacikistan arasında gerilimi artırdı. Bunların yanı sıra, Özbekistan, bölgede Rusya'nın askerî olarak etkinliğinin arttığını düşündüğü girişimlere katılmama yaklaşımını sürdürdü. Aralarındaki sorunlara rağmen Orta Asya ülkeleri, Şı̈O bünyesinde bölgenin önemli aktörleri olan Çin ve Rusya'ya karş1 benzer tutum geliştirerek bu iki gücü, birbirine karşı sınırlamaya önem verdiler. Orta Asya ülkeleri, bölgede, gündemin tek bir dominant gücün çıkarları ve öncelikleri doğrultusunda belirlenmesini arzu etmemektedir. Buna karşılık, Çin ve Rusya, ABD'nin bölgeye etkisini engellemeye yönelik ortak tutum geliştirirken, örgüt içinde bu iki güçten birinin etkinlik kazanması, diğeri tarafından sınırlandırılmaya çalışılmaktadır. Bu bağlamda, Çin, bölgede serbest ticareti savunmasına karşın, diğer üye ülkeler, ekonomilerinin kontrol edileceği düşüncesiyle buna yanaşmamakta; Çin'in önerdiği kredilerin, ekonomik karar alma 
Şanghay İşbirliği Örgütü:

Çıkarlar/Öncelikler ve Bölgesel İş Birliği Arasında Bir Denge Arayışı

süreçleri üzerinde, Pekin'in siyasi egemenliğini artıracağından endişe duymaktadır. Benzer biçimde Çin, Asya'daki nüfuzunu artırmak için üyeliği genişletme konusunda istekli olmasına karşın, Rusya ve Orta Asya ülkeleri, Asya'nın geri kalanıyla büyük ölçekli ekonomik ilişki kurma kapasitesine sahip olmadıklarını düşündüklerinden, Çin'in bu yaklaşımını desteklememektedir. Rusya, Orta Asya'daki pozisyonunu olumsuz etkileyebileceğini düşünerek, Çin'in bölgedeki bu tür girişimlerine temkinli yaklaşmakta, bu ülkeyi, ŞIOO bünyesinde dengelemeye çalışmaktadır.

Uluslararası politikada etki kapasiteleri daha düşük olan Orta Asya ülkelerinin bölgesel iş birliği bağlamında Şı̈Ö üyeliği gerekçeleri şu şekilde sıralanabilir:

- Bölgede sadece bir devletin çabasıyla etkili bir biçimde çözülemeyecek ulusötesi sorunların varlığı;

- Bu sorunların çözümünde, bölgesel bir uluslararası kuruluş bünyesinde, diğer üyeler ile aynı yetki ve sorumluluklara sahip eşit bir üye olmayı çıkarlarına uygun görmeleri;

- ŞïÖ’nün, devletlerin içişlerine müdahalede bulunulmaması prensibini benimsemesinin, genç sayılabilecek bu devleterin iç istikrarlarını güçlendirmelerine uygun ortam sağlaması.

Benzer biçimde, Şi̇Ö'nün ulusal egemenlik ve toprak bütünlüğü ilkelerinin önemini vurgulaması ve üye hükümetlerin uygun gördükleri güvenlik politikalarını takip etme hakkı olduğunu savunması, bölgedeki liderlerin konumlarını güçlendirmelerine katkı sağlamaktadır. İlave olarak, bölgesel istikrar, radikalizm karşıtllı̆g1, enerji güvenliği ve dış etkiye karşı tutum geliştirmeyi de içine alan Şî̈'nün iç politikasındaki karşılıklı güven, karş1lıklı yarar, eşitlik, karşılıklı danışma, kültürel çoğulculuğa saygı, birlikte kalkınma prensiplerinin de bu ülkelerin bölgesel iş birliğini tercih etmelerinde etkili olduğu ifade edilebilir.

Henüz 20 yılını tamamlamamış bölgesel bir örgüt olarak ŞiÖ’nün, gelecekte uluslararası alanda üstleneceği sorumluluklar henüz tam olarak belirgin değildir. ŞïÖ Stratejisi'nde örgütün geleceği askerî ve politik bir blok veya uluslarüstü yönetişim organları olan bir ekonomik entegrasyon birliği olarak öngörülmemekte, çok formatlı bölgesel bir 
324

Güvenlik Stratejileri

Cilt: 15

Sayı: 30

örgüt olarak gelişmesi amaçlanmaktadır. Ukrayna ve Suriye krizlerini, Afganistan'daki güvenlik problemini ve İran'ın nükleer çalışmalarını gündemine almasi; siber/bilgi güvenliği konusunda küresel norm ve standartların belirlenmesine yönelik girişimlerini sürdürmesi, Şi̇Ö'nün gelecekte konvansiyonel ve yeni küresel/bölgesel sorunlarda daha etkin rol üstlenebileceğinin işaretleri olarak görülebilir.

ŞiÖ’nün gelecekte uluslararası sistemde etkinliğini artırabilmesi, bu çalışmada da ileri sürülen "uluslararası örgütlerde başat güçlerin çıkarlarının uyumlaştııılması" hipotezine uygun tutum geliştirilmesini gerekli kılmaktadır. Örgüt bünyesinde uygun güç dağılımına olanak sağlayan birden fazla aktörün bulunması ve bu aktörlerin örgüte ilgilerinin sürmesinin sağlanması halinde Şı̈Ö'nün, önümüzdeki süreçte uluslararası alanda etkisini artırarak varlığını sürdüreceği ifade edilebilir. Bu anlamda, Hindistan'ın ŞiÖ üyesi olmasının, örgüte güç kazandırdığı düşünülmektedir. ŞīÖ bünyesindeki başat aktörlerden Rusya ve Çin arasında son yıllarda imzalanan anlaşmalarla geliştirilen kapsamlı iş birliğinin, gelecekte, bu ülkelerin, Şï̈’de çıkar ve önceliklerinin uyumlaştırılmasına zemin oluşturabileceği ileri sürülebilir. ŞïÖ'nün, diğer üye ülkelerin aralarındaki sorunları uzlaşmayla çözümleme kapasitesini geliştirmesinin ve uluslararası sistemdeki rol ve kimliğini belirleyerek yoğunlaşacağı alanları açık olarak tespit etmesinin, etkinliğini artırmaya yönelik olarak gelecekte üzerinde durması gereken konular olduğu, vurgulanmalıdır. İlave olarak, Şı̈Ö'nün, bölgedeki diğer uluslararası örgütlerle etkin iş birliği sağlanması halinde; Büyük Avrasya veya Avrasya ortaklığ fikrinin gerçekleşmesinde, güçlü bir platform olarak öne çıkabileceği öngörülebilir. Bu tür bir gelişme, ilgili tarafların istekli ve kararlı olmalarına bağlı olmasının yanı sıra, kapsamlı bir bölgeselleşme bağlamında, uzun zaman alacak koordinasyon ve uyumlaştırma sürecini gerektirecektir.

\section{Summary}

Kazakhstan, Kyrgyzstan, and Tajikistan started negotiations with China to solve the border problems, originating from the Soviet era, and determine the boundaries according to the new political situation 
Şanghay İşbirliği Örgütü:

Çıkarlar/Öncelikler ve Bölgesel İş Birliği Arasında Bir Denge Arayışı

in Central Asia in the early 1990s, after the dissolution of the Soviet Union. The resolution of border disputes within a short period and including Russia in these talks has contributed to stability in the region significantly. Upon this confidence-building development, the countries of the region decided to strengthen their relations in 1996, within the framework of the mechanism known as the Shanghai Five. Then, with the participation of Uzbekistan, a consensus was reached on the promotion of mutual trust, good neighborly relations, and the development of comprehensive cooperation in the region. This positive atmosphere paved the way to establish the Shanghai Cooperation Organization (SCO) and the declaration of the SCO was signed in 2001. In the beginning, the SCO took on the role of an international platform, providing political equality and legality in strengthening the legitimacy of the governments of the newly founded countries of the region.

The SCO member countries that have significant differences in their capacity to create influence in the international environment have different expectations in this organization. Central Asian countries attempt to limit the major actors of the region, China and Russia, to each other. These countries do not wish the agenda in the region to be determined in line with the interests and priorities of a single dominant power. Although China, one of the major powers of the organization, defends free trade in the region, other member countries do not adopt this approach. Since Russia and other Central Asian countries think that they do not have the capacity to establish large-scale economic relations with the rest of Asia, they do not support China aiming at increasing its influence in Asia by expanding the membership of the SCO. Considering that China might weaken its position in Central Asia, Russia is cautious about such initiatives in the region and is trying to balance this country within the SCO.

As a regional organization, the responsibilities that the $\mathrm{SCO}$ will assume in the future are not yet evident. In the SCO Strategy, the organization's future is foreseen neither as a union of economic integration nor as a political or military block with transnational governance bodies, which it aims to develop as a multi-format regional organization. Nevertheless, examining some current hot issues in 
326

Güvenlik Stratejileri

Cilt: 15

Sayı: 30 international relations such as the crisis in Ukraine and Syria, the insecurity in Afghanistan and Iran's nuclear deal, and the continuation of its efforts to determine global norms and standards in the field of cyber/information security may be seen as indicators of the fact that the SCO can play a more effective role in the future in conventional and new global/regional issues.

Having more than one strong actor in the organization provides appropriate power distribution in the SCO. However, increasing the effectiveness of the SCO in the international system in future, as claimed in this study, requires the development of the attitude towards the harmonization of the interests of the dominant powers in this international organization. At this point, it can be expressed that, the comprehensive cooperation between Russia and China, the main actors in the organization, through the approved treaties in recent years, may serve as a basis for harmonization of interests and priorities of these countries in the SCO.

The SCO has also the possibility to stand out as a strong international platform in the realization of the idea of a Greater Eurasia or Eurasia partnership in the event of effective coordination with other international organizations in the region, but it should be highlighted that such development needs more time and depends on developments on a global scale.

A history of less than two decades may not be enough to establish a strong international organization with its conditions, norms, and structures. However, in a period where debates regarding the reshaping of the international order lasting, having member countries such as China and Russia which have veto power in the UN, and having a member such as China which keeps its status as a rising power, show us that the SCO has the capacity to have an impact on international relations very deeply in the context of ally relation in the future. 
Şanghay İşbirliği Örgütü:

Çıkarlar/Öncelikler ve Bölgesel İş Birliği Arasında Bir Denge Arayışı

KAYNAKÇA

Kitaplar ve Kitap Bölümleri

BOZDAĞLIOĞLU, Yücel, "Liberalizm", ÇAKMAK Haydar (ed.), Uluslararası İlişkiler, Giriş, Kavram ve Teoriler içinde Platin, Ankara 2007.

ÇAĞIRAN, Mehmet Emin, Uluslararası Örgütler, Turhan kitabevi, Ankara 2013.

GUANG, Pan, "The SCO's Success in Security Architecture" in Ron Huisken (ed.)

The Architecture of Security in the Asia-Pacific, ANU Press, 2009.

LAURELLA, Marlene and PEYROUSE Sebastien, "The Chinese Question" in Central Asia: Domestic Order, Social Changes, and the Chinese Factor, Hurst and Company, London, 2012.

LO, Bobo, Axis of Convenience Moscow, Beijing and The New Geopolitics, Brookings Institution Press, Washington 2008.

SÖNMEZOĞLU, Faruk (der.), Uluslararası İlişkiler Sözlüğ̈̈, 4. Basım, DER Yayınları:184, İstanbul 2010.

STEIN, Arthur A., "Neoliberal Institutionalism", Christian Reus-Smit and Duncal Snidal, in The Oxford Handbook on International Relations, Oxford University Press, New York, 2008.

Yearbook of the International Law Comission, Vol. I, 2003.

Makaleler

ALIMOV, Rashid, "The Shanghai Cooperation Organisation: Its role and place in the development of Eurasia", Journal of Eurasian Studies, Asia-Pacific Research Center, Hanyang University, 2018.

ALLISON, Roy, "Virtual regionalism, regional structures and regime security in Central Asia", Central Asian Survey, Vol. 27, No. 2, June 2008.

-------, "Regionalism, regional structures and security management in Central Asia," International Affairs, 80, 3, 2004, 463-483.

AMBROSIO, Thomas, "The Architecture of Alignment: The Russia-China Relationship and International Agreements", Europe-Asia Studies, 69:1, 2017, 110-156.

ARIS, Stephen, "Shanghai Cooperation Organization Mapping Multilateralism in Transition”, International Peace Institute, No: 2, 2013.

-------, "The Response of the Shanghai Cooperation Organisation to the Crisis in Kyrgyzstan", Civil Wars, 14, No. 3, 2012.

-------, "The Shanghai Cooperation Organisation: 'Tackling the Three Evils'. A Regional Response to Nontraditional Security Challenges or an Anti-Western Bloc?" Europe-Asia Studies, 61:3, 2009, 457-482.

BOLAND, Julie,'Ten Years of the Shanghai Cooperation Organization: A Lost Decade? A Partner for the U.S.?" 21 'st Century Defense Initiative Policy Paper, 20 June 2011.

DE HAAS, Marcel, "War Games of the Shanghai Cooperation Organization and the Collective Security Treaty Organization: Drills on the Move!" The Journal of Slavic Military Studies, 29:3, 2016.

KASHIN, Vasily, Alexander Lukin, "Russian-Chinese Security Cooperation in Asia", Asian Politics \& Policy, Volume 10, Number 4, 614-632.

KERR, David and Laura Swinton, "China, Xinjiang, and the transnational security of Central Asia”, Critical Asian Studies 40 (1), 2008. 
İbrahim ARSLAN

328

Güvenlik

Stratejileri

Cilt: 15

Sayı: 30

LUKIN, Alexander, "Russian-Chinese Cooperation in Central Asia and the Idea of Greater Eurasia", India Quarterly, 1-14, Indian Council of World Affairs (ICWA) 2019.

NICKLAS, Norling, and Niklas Swanstrom, "The Shanghai Cooperation Organization, Trade, and the Roles of Iran, India, and Pakistan", Central Asian Survey, 26(3), September 2007.

PLATER-ZYBERK, Henry and Andrew Monaghan, "Strategic Implications of the Evolving Shanghai Cooperation Organization", United States Army War College Press SSI, 2014.

SONG, Weiqing, "Interests, Power and China's Difficult Game in the Shanghai Cooperation Organization (SCO)", Journal of Contemporary China, Taylor \& Francis, Vol: 23, No: 85, 2014.

WEITZ, Richard, "What happened to the SCO?" Diplomat, May 17, 2010.

YUAN, Jing Don, "Beijing's institutional-balancing strategies: rationales, implementation and efficacy", Australian Journal of International Affairs, 2018.

\section{Bildiri, Karar ve Raporlar}

"An Updated Draft of the Code of Conduct Distributed in the United Nations-What's New?", 10 February 2015, CCDCOE NATO Cooperative Cyber Defence Centre of Excellence, https://ccdcoe.org/updated-draft-code-conduct-distributed-united-nationswhats-new.html, (Erişim Tarihi: 22.5.2018)

Agreement on Cooperation in Ensuring International Information Security between the Member States of the Shanghai Cooperation Organization

"Charter of the Shanghai Cooperation Organization", Article 16 Decisions-Taking Procedure

"Cooperation Between UN, Shanghai Cooperation Organization Dynamically Expanding, in Shared Quest for Peace, Prosperity, Says Secretary-General, in Message" SG/SM/12953, 11 June 2010, https://www.un.org/press/en/ 2010/sgsm12953.doc.htm

"Declaration by the Heads of the Member States of theShanghai Cooperation Organization", Article IV.

"Declaration of Shanghai Cooperation Organization", People's Daily, June 15, 2001, http://en.people.cn/200106/15/eng20010615_72738.html, (Erişim Tarihi: 22.5.2018)

"Declaration on the establishment of the Shanghai Cooperation Organization", p. 1, http://www.gsdrc.org/docs/open/regional-organisations/sco,\%202001,\%20establishing \%20declaration.pdf (Erişim Tarihi: 15.4.2018)

Development Strategy of the Shangai Cooperation Organization until 2025

"Joint Communique following the 16th Meeting of the SCO Heads of Government Council”, December 2017.

"Joint Communique, Twelfth meeting of the Council of Heads of Government (Prime Ministers) of the Member States of the Shanghai Cooperation Organization", Article 4.

"Memorandum of Understanding between the Secretariat of the Association of Southest Asian Nations (Asean Secretariat) And the Secretariat of the Shanghai Cooperation Organization (SCO Secretariat)", Jakarta, April 21, 2005.

"Press release on the results of the Shanghai Cooperation Organisation Heads of State Council Meeting”, Astana 8-9 June 2017. 
Şanghay İşbirliği Örgütü:

Çıkarlar/Öncelikler ve Bölgesel İş Birliği Arasında Bir Denge Arayışı

"Regulation on Admission of New Members to Shanghai Cooperation Organization", 1.2 of General Provisions.

"The Astana declaration of the Heads of State of the Shanghai Cooperation Organization", June 9, 2017.

"The memorandum of understanding between the Secretariat of the Collective Security Treaty Organization and the Secretariat of the Shanghai Cooperation Organization", Dushanbe, October 5, 2007.

"The Shanghai Convention on combating terrorism, separatism and extremism", https://eurasiangroup.org/files/uploads/files/International_ legal_documents/Conventions/ The_20Shanghai_20Convention.pdf, (Erişim Tarihi: 22.5.2018)

UNODC Press Release, "Shanghai Cooperation Organization sign agreement to boost international health, safety and security", 14 June 2011, https://www.unodc.org/unodc/ en/press/releases/2011/June/ unodc-shanghai-cooperation-organization-sign-agreement-toboost-international-health-safety-and-security.html (Erişim Tarihi: 19.5.2018)

\section{İnternet Kaynakları}

"Collective Security Treaty Organization (CSTO)", https://www.global security.org/military/world/int/csto.htm (Erişim Tarihi: 3.5 .2018 )

"Collective Security Treaty Organization (CSTO), Collective Rapid Reaction Forces", https://www.globalsecurity.org/military/world/int/ csto.htm (Erişim Tarihi: 27.5.2018)

"Eurasian Economic Community (EurAsEC)",en.gosnadzor.ru/international/ organizations/eurasec/ (Erişim Tarihi: 2.5.2018)

GABUEV Alexander, "Bigger, Not Better: Russia makes the SCO a Useless Club", Carnegie Moscow Center, 23.06.2017, https://carnegie.ru/commentary/71350 (Erişim Tarihi: 20.5.2018)

"General information about the SCO Secretariat", http://eng.sectsco.org/secretariat/ (Erişim Tarihi: 22.5.2018)

GHIASY Richard and ZHOU Jiayi, "The Silk Road Economic Belt: Considering security implications and EU-China cooperation prospects", SIPRI, February, 2017, https://www.sipri.org/publications/2017/other-publications/silk-road-economic-belt (Erişim Tarihi: 2.6.2018)

"History of the SCO", http://eng.sectsco.org/docs/about/faq.html\#2, (Erişim Tarihi: 22.5.2018)

"Jiang: Perfecting 'Shanghai Five' Mechanism', People's Daily, July 5, 2000, http://en.people.cn/english/200007/05/eng20000705_44747.html (Erişim Tarihi: 15.4.2018) KUCERA Joshua, "Russia "Increasingly Distrustful" Of SCO", Mar 5, 2013, https://eurasianet.org/s/russia-increasingly-distrustful-of-sco (Erişim Tarihi: 4.5.2018). Ministry of Foreign Affairs Islamic Republic of Afghanistan, "Shanghai Cooperation Organization (SCO) Afghanistan Contact Group Meeting", Oct 11, 2017, http://mfa.gov.af/en/news/shanghai-cooperation-organization-sco-afghanistan-contactgroup-meeting, (Erişim Tarihi: 12.5.2018)

"Rashiad Alimov: Fighting drug trafficing is among SCO's priorities", 2017/03/11, http://eng.sectsco.org/news/20170311/226233.html, (Erişim Tarihi: 10.5.2018) 
İbrahim ARSLAN

330

Güvenlik

Stratejileri

Cilt: 15

Sayı: 30

"Regional Anti-Terrorist Structure", http://eng.sectsco.org/ structure/\#6, (Erişim Tarihi: 22.5.2018)

"Rogun Hydropower Project", https://www.salini-impregilo.com/ en/projects/inprogress/rogun-dam.html\#, (Erişim 25.5.2018)

https://eurasianet.org/s/russia-increasingly-distrustful-of-sco (Erişim Tarihi: 4.5.2018)

"Russia's President Putin proposes SCO energy club", Media group/ Tajihistan Asia-

Plus, http://www.news.tj/en/news/russias-president-putin-proposes-sco-energy-club, June 15, 2006, (Erişim Tarihi: 1.6.2018)

"SCO exercises Peace Mission - 2016 completes in Kyrgyzstan", KABAR, http://old.kabar.kg/eng/society/full/17005 Erişim Tarihi: 10.4.2018)

"SCO University project: definitely successful", 08.06.2011, http://infoshos.ru/ en/?idn=8338 (Erişim Tarihi: 20.5 .2018)

"Structure of the Shanghai Cooperation Organisation", http://eng.sectsco.org/ structure/, (Erişim Tarihi: 20.5.2018)

"Tajikistan Civil War", https://www.globalsecurity.org/military/world/war/ tajikistan.htm, (Erişim Tarihi: 14.5.2018)

TELES FAZENDEIRO Bernardo, “Uzbekistan's Suspension of CSTO Membership: Policy as Usual in Tashkent",E-International Relations, Jul 19 2012, http://www.eir.info/2012/07/19/uzbekistans-suspension-of-csto-membership-policy-as-usual-intashkent/ (Erişim Tarihi: 7.5.2018)

The Shanghai Cooperation Organization, "The SCO and ESCAP: Cooperation prospects", http://eng.sectsco.org/news/20170512/ 267457.html (Erişim Tarihi: 12.5.2018)

"The Shanghai Cooperation Organisation", http://eng.sectsco.org/ about_sco/ (Erişim Tarihi: 15.4.2018)

The World Bank, "Countries and Economies", https://data.worldbank.org/country (Erişim Tarihi: 10.4.2018) 